\title{
Impact of the Plugged-in and Unplugged Chemistry Computational Thinking Modules on Achievement in Chemistry
}

\author{
Samri Chongo ${ }^{1}$, Kamisah Osman ${ }^{1 *}$, Nazrul Anuar Nayan ${ }^{1}$ \\ ${ }^{1}$ Universiti Kebangsaan Malaysia, MALAYSIA
}

Received 15 September 2020 - Accepted 25 February 2021

\begin{abstract}
Computational thinking (CT) is one of the systematic tools in problem solving and widely accepted as an important skill in the 21st century. This study aimed to identify the effectiveness of the Chemistry Computational Thinking (CT-CHEM) Module on achievement in chemistry. This study also employed a quasi-experimental design with the participation of 85 form four students in Malaysia. The three types of teaching approaches, namely CT-CHEM Module Plugged-in (CTMP), CT-CHEM Module Unplugged + Plugged-in (CTMUP) and conventional method (CM), were systematically designed and implemented. The achievement of students was measured using an achievement test, where validity and reliability were justified and two-way ANCOVA was used to analyse the data. Findings confirmed that the achievement of students in chemistry is significantly higher in the CTMP group as compared with the CTMUP and CM groups. Instead, gender had no significant effect on students' chemistry achievement. This study concludes that when students were exposed to teaching and learning strategies by integrated CT through plugged-in strategy more effective than a combination of plugged-in and unplugged. Plugged-in visualisation activities are more effective in increasing the understanding and achievement of students compared with the combination of plugged-in and unplugged activities. Plugged-in through visualisation activities is more effective than the combination of plugged-in and unplugged. This is because, the abstract concept in electrochemistry is easier to understand by students through the visualisation activity approach using a computer in explaining the important concepts in the topic and because the whole content is interrelated.
\end{abstract}

Keywords: computational thinking, plugged-in, unplugged, problem solving, chemistry learning

\section{INTRODUCTION}

In the era of digital economy, computational thinking (CT) skills must be implemented in the education system in line with the passage of time to produce a globally competitive society. CT skills are aligned with the needs of 21st century skills. Therefore, everyone must acquire and use them in problem solving situation faced in life more efficiently (Haseski, Ilic, \& Tugtekin 2018). Skills in CT are considered as the key to 21st century skills for all students and have preceded initiatives in the curriculum (Yadav, Hong, \& Stephenson, 2016). These 21st century skills or knowledge should be applied in new situations (Pellegrino \& Hilton, 2012) and be able to solve problems in daily life. CT has been executed in the education system in Malaysia that began in 2017 by introducing basic computer science subjects in secondary schools. One of the main objectives is to help students solve complex problems through CT using computer-based problem solving (MOE, 2016a). The emphasis on CT skills in the education system today is due to the development of the digital economy. The rapid changes in technology and economics that took place in the 21st century have changed the skills needed in the workplace (Kamisah \& Lay, 2020). Therefore, CT skills should be possessed by everyone in the 21st century in solving problems more efficiently (Haseski, Ilic, \& Tugtekin, 2018) and must be integrated in the education system through computer science subjects and integration with other subjects such as chemistry subjects.

(c) 2021 by the authors; licensee Modestum. This article is an open access article distributed under the terms and conditions of the Creative Commons Attribution License (http://creativecommons.org/licenses/by/4.0/).

\samrichongo@gmail.com $\square$ kamisah@ukm.edu.my (*Correspondence) $\square$ nazrul@ukm.edu.my 


\section{Contribution to the literature}

- This study shows the positive impact integration of CT skills with the chemistry subject.

- This study contributes to the problem-solving approach using CT skills with plugged-in and the combination of unplugged and plugged-in activities.

- This study provides information specifically on the application of five CT skills namely decomposition, generalisation, algorithmic abstraction and evaluation in the chemistry subject.

Science, Technology, Engineering, and Mathematics (STEM) has become a popular term in education world wide (Gao et al., 2020) and chemistry is the centre knowledge of science (Adesoji, Omilani, \& Dada, 2017). Thus, students must master it to be competent in the field of STEM which is the backbone in the development of a country. However, Malaysian students who take chemistry are only few, based on the stream intake of only $19 \%$ of 447000 students after they sit for the Form Three Assessment (PT3) (Faizatul, 2020). Hence, students should master CT skills through integration with the chemistry subject in T\&L especially in the electrochemistry topic, which is considered difficult (Jong \& Treagust, 2002; Schmidth, Marohn, \& Harrison, 2007). The implementation of CT skills in the chemistry subject in schools is in line with the goals of the chemistry curriculum which is to provide students with the knowledge and skills of science and technology and enable them to solve problems and making decisions in daily life (MOE, 2012). Accordingly, students must master chemistry which is the basis in science to be competent in STEM as the need to get hold of 21st century skills (Lay \& Kamisah, 2017). The integration of chemistry with computer science is a platform to change the paradigm of students from a user to a creator to generate new ideas in the 21st century (MOE, 2016a). CT skills are recognised as the best system in solving problems and intellectual skills in the 21st century (Sridaran \& Shailaja, 2015). Therefore, CT should be integrated with any subjects especially chemistry and become the skills needed by each individual in this century in solving problems more efficiently (Haseski, Ilic, \& Tugtekin, 2018). The mastery of CT skills and the knowledge of chemistry are expected to produce a generation that can create new materials by using the computer science technology for the needs of society.

Computational science is the integration of mathematics, computer science and any other discipline in education and can be an effective methodology to support students to solve a STEM problem by using simulation (Psycharis, 2018). Computer science core instruction aims to provide a detail understanding of dynamic processes, such as the working of the flow of information or algorithm between computing entities (Fouh, Akbar, \& Shaffer, 2012). Computer science is not just about programming and coding, but it is more important in exposing students to $\mathrm{CT}$ that involves problem solving using computer science concepts (Lye
\& Koh, 2014). According to Wing (2006), CT is considered as a way to solve problems, they designed systems and understand human behaviour based on the basic concepts in computer science. Although there are many studies on problem solving (Bers et al., 2014; Swaid, 2015; Tanujaya, Mumu, \& Margono, 2017) and higher other thinking skills (HOTS) (Salihuddin et al., 2016) but few teachers have been exposed to instruction that integrates technology and engineering (Brand, 2020; Nelson et al., 2015) as a way to solve his problem in chemistry. According to Barr and Stephenson (2011), CT is one of the tools used in active problem solving and suggestions through integration with other subjects, such as science, mathematics, language arts and social studies with focused on computational thinking concepts (Barr \& Stephenson, 2011; Reichert, Couto Barone, \& Kist 2020).

Problem solving is fundamental to the actions of all human beings and requires strategies, higher order thinking skills (Reddy, 2020) and major objectives of science education (Shakhman \& Barak, 2019). The apparent difference between the problem-solving approaches that have been implemented before against integrating CT skills is that the latter is more systematic. Csizmadia et al. (2015) affirmed that CT skills are the best approach in solving because they involve logical thinking where problems are solved, and procedures and systems are better and easier to understand. In CT, students start to work with algorithmic problem solving and computational methods in secondary schools (Barr \& Stephenson, 2011). The findings of Samri, Kamisah, and Nazrul Anuar (2020) showed the relationship between CT skills and mathematics achievement is significant. Therefore, important to analyze CT from the perspective of mathematics teaching is crucial (Reichert, Couto Barone, \& Kist, 2020).

Computational Modeling and Simulation Technology is a computational pedagogy introduced by Yasar et al. (2016) and gives a new content domain of computational science. Psycharis and Kotzampasaki (2019) integrated Computational Science Experiment and Engineering Education Epistemology as a computational model called as Computational STEM Pedagogy. These models using programming and technology as engineering design to solve problems. However, aspect of the technology is difficult to learn (Psycharis \& Kotzampasaki, 2019), especially that it involves programming. Olabe et al. (2014) found a new 
pedagogical approach such as simple programming, using Scratch that capable of solving real life problems. The greatness of CT is not only reveals the way the problems are solved but also critical, creative, logical thinking, formulates the solution process as well as shaping the attitudes, self-confidence and communication (ISTE \& CSTA 2011). Critical thinking is a generally recognised educational ideal at all levels of the educational process (Sustekova, Kubiatko, \& Usak, 2019). So, the role of CT is not just to recognise Computer Science to CT as programming but more than that by making CT a part of our lives (Voogt et al., 2015). The use of computers through simple programming such as Scratch provides a unique opportunity to relate to the concept of CT (Kalogiannakis \& Papadakis, 2017; Leon \& Robles, 2015; Papadakis et al., 2016; Smith \& Burrow, 2016). Integrating CT into the curriculum has transcended other disciplines and competencies in the 21st century (Voogt et al., 2013).

\section{LITERATURE REVIEW}

The Chemistry Computational Thinking (CT-CHEM) Module is a module that integrates computational thinking with the Chemistry subject. This module comprises two types of teaching approaches, namely, the Computational Thinking Module Plugged-in (CTMP) and the Computational Thinking Module Unplugged and Plugged-in (CTMUP). This module can help students understand abstract concepts in the electrochemistry topic by integrating CT skills. The implementation of CT concepts in schools can be conducted through two approaches that are unplugged and plugged-in (French Academy of Sciences, 2013; Tsarava et al., 2017). The process of CT that is performed using computers with programming, such as Scratch and Python, is plugged-in, and the one without a computer is unplugged (Tsarava et al., 2017). GarcíaPeñalvo et al. (2016) also explained that the unplugged approach is a hands-on activity that promotes problem solving and logic without using a computer. The teaching approach in the CTMP is plugged-in, whilst the CTMUP employs an unplugged and plugged-in teaching approach. Plugged-in activities in this module use Scratch 3.0 whilst unplugged activities utilise magnetic boards and related stationery in the chemistry subject.

Chemistry is a difficult subject (Gulacar \& Bowman, 2014; Gulacar, Milkey, \& Mclane, 2019), especially in the electrochemistry topic are abstract in nature making it difficult to teach and there are many misconceptions amongst students (Garnett \& Treagust, 1992a, 1992b; Novrita Mulya, 2012). At the macroscopic level, students must understand the concept of electrolytes and nonelectrolytes before understanding the concept of electrolysis, The process of electrolysis which is to understand the movement of ions and electrons at the microscopic level and have to translate in the process of changes into chemical formulas and equations at the symbolic level (Kamisah \& Lee, 2013). Yochum and Luoma (1995) explained that students face problems in the electrochemistry topic because they cannot see and create imagination at the microscopic level. Therefore, the teaching approaches of teachers should involve all the three levels, which are macroscopic, microscopic and symbolic (Adesoji \& Omilani, 2012; Kamisah \& Lee, 2014; Roziah, 2005), to understand the concepts in electrochemistry topic. Computer technology has changed the way humans work in all aspects of life. Although the human mind is capable of solving big problems, the ability of humans to think is rather limited (Barr, Harrison, \& Conery, 2011). The presence of computers should be utilised in solving problems related to the electrochemistry topic by integrating CT skills through projects produced by students using Scratch.

The CTMP teaching approach is a teaching and learning (T\&L) activity that fully uses plugged-in by using Scratch. Programming like Scratch is one form of simple programming at the initial stage (Tsarava et al. 2017). In Scratch, graphic blocks must only be controlled and moved. The graphics programming environment is relatively easy to use and allows Scratch users to focus on design and creation and avoid syntax issues in programming (Grover \& Pea, 2013). The qualitative study of Saltan and Kara (2016) on ICT teachers in the service shows a positive acceptance of Scratch because it is easy and convenient to use. Qin (2009) asserted that integration of CT with the biology subject can improve computer skills, critical thinking and problem solving. Findings from previous studies have proved that the use of Scratch can help solve problems amongst students in understanding a concept (Kalelioğlu \& Gülbahar, 2014; Moreno-León, Robles, \& González 2015; Su et al., 2014) and further improve their achievement (Basu, Biswas, \& Kinnebrew 2017; Rodriguez, Rader, \& Camp 2016). Learning with the use of computer has been asserted to improve achievement in the chemistry subject (Gambari et al., 2016). The use of the Scratch program is a method in problem solving because Scratch programming makes one think (Resnick et al., 2009) in solving a problem. Problem-based learning is a teaching method that encourages students to achieve academic success (Smit, De Brabander, \& Martens, 2016) and understand a concept (Rubiah, 2016).

The CTMUP teaching approach begins with unplugged activities at the initial stage until the middle phase of the electrochemistry topic and then followed by plugged-in activities. There are several studies that conducted unplugged activity (Brackmann et al., 2017; Rodriguez et al., 2017; Rodriguez, Rader, \& Camp, 2016; Thies \& Vahrenhold, 2013) in applying CT. Past studies have also validated that unplugged activities applied from computer science are effective in implementing CT skills and being an alternative to traditional methods (Lambert \& Guiffre, 2009; Thies \& Vahrenhold, 2013). 


\section{Learning \\ Theory}

Teaching Approaches

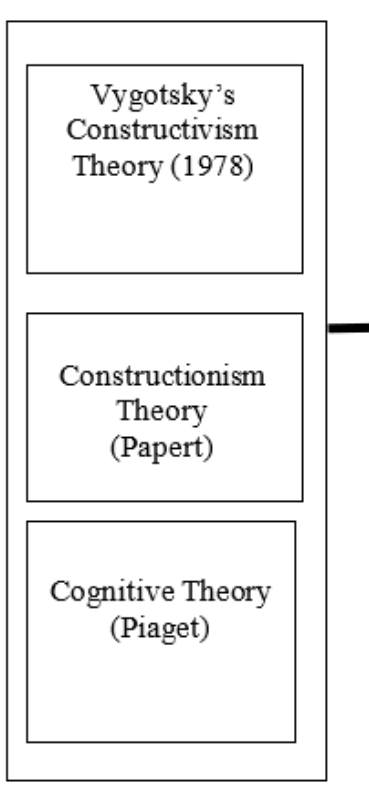

Learning

Outcomes

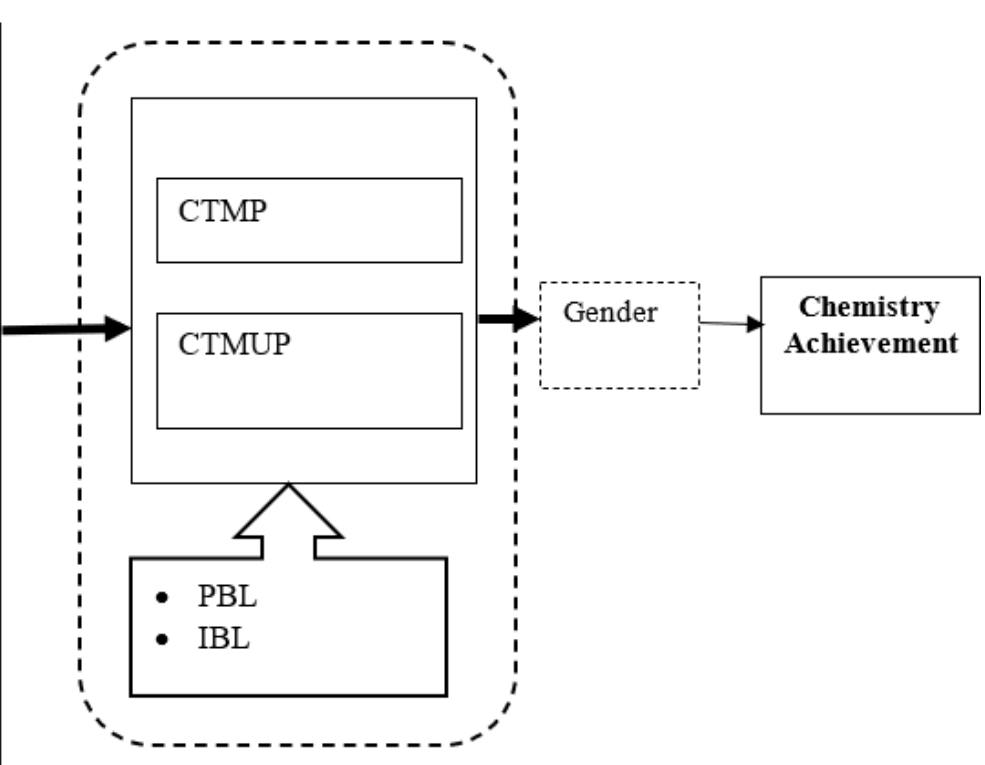

Figure 1. Research Conceptual Framework

Note

PBL : Project Based Learning (PBL)

IBL : Inquiry Based Learning (IBL)

CTMP : CT-CHEM Module Plugged-in

CTMUP : CT-CHEM Module Unplugged + Plugged-in

Amongst the advantages of unplugged approaches involve kinesthetic or physical activities (Curzon et al., 2009). Activities or projects produced by students outside of the learning period can provide support for educational goals (Rodriguez, Rader, \& Camp 2016) in promoting informal education. However, few studies have been conducted to adapt extra-curricular activities in schools (Rodriguez, Rader, \& Camp, 2016) and combined plugged-in and unplugged activities in implemented CT skills in schools.

CT skills must be adapted in schools, especially in the chemistry subject, to abridge the gap between male and female in the STEM field. According to Shute et al. (2017), female students have a low number in the field of STEM, especially as soon as they entered colleges or universities. The findings of this study are also supported by the study of Mann and Diprete (2013) found that males are more dominant in physical science or engineering compared females who are more dominant in biology. You (2013) argued that male students $(74.1 \%)$ are more likely to choose a STEM major than female students (25.9\%). Similarly, You (2013), and Mann and Diprete (2013) verified that, in Malaysia, the percentage of students who obtained their first degree in engineering and technology is dominated by males. In 2015 first degree in engineering by male (64\%) and female $(36 \%)$ whilst in technology the involvement of male $(52 \%)$ and female $(48 \%)$ and in the field of Science male $(30 \%)$ and female (70\%) (Halimaton, 2017). Although there are differences in involvement in the technical field, the perception of the evaluation of STEM in the context of gender is statistically insignificant (Meng, Idris, \& Eu, 2014). Similarly, the results of PISA in Malaysia in 2015 on Science (scientific literature) and Mathematics show no significant differences according to gender (MOE, 2016b). Moreover, many studies have corroborated that men are more involved in computer science education (Mellström, 2009; Vitores \& Gil-juárez, 2016). Although gender issues are inconsistent, they must still be considered so that the gap of the involvement of males and females in certain areas can be balanced. Consequently, the CT-CHEM Module which highlights two teaching approaches, namely, CTMUP and CTMP is to identify its effectiveness on achievement in chemistry across gender.

\section{CT-CHEM Module Conceptual Framework}

The CT-CHEM Module was developed on basis of the MRKK Model (Morrison, Ross, Kalman, \& Kemp, 2013). In evaluating the effectiveness of this module, it is guided by two theories that are constructivism and constructionism. Teaching approaches are Inquiry Based Learning and Project-Based Learning. The CT-CHEM Module includes two form or approaches, namely, the CT-CHEM Module Unplugged and Plugged-in (CTMUP). The CTMUP teaching approach requires students to produce two projects, whilst CTMP requires three projects. Figure 1 summarises the conceptual framework in this study. 
Cognitive theory is a learning theory that emphasises internal mental processes (Alice et al., 2008). According to Piaget, the ability of person to manage information and knowledge occurs in stages. This process begins with an existing scheme in the cognitive structure of a person and is followed by assimilation, equilibration and accommodation (Schunk, 2012). In the development of the CT-CHEM Module, researchers have included text and graphics in the CT-CHEM Module for the pluggedin and unplugged approaches as it can enhance cognitive processes (Orlich et al., 2010).

In constructivist learning theory, students build new knowledge with the support of existing knowledge. This learning occurs actively because the knowledge received by students must be coordinated with the existing knowledge and the interaction amongst students also occurs actively (Vygotsky, 1978). The struggle by students in the early stages of the integration of CT plugged-in, can be reduced through scaffolding. The scaffolding approach is better known in the field of CT (Grover \& Pea, 2013), and it is highly effective in performing problem-based tasks. (Basu, Biswas, \& Kinnebrew, 2017).

Constructionism learning theory emphasises that the construction of new knowledge occurs when students are involved in producing a project or artefact (Papert \& Harel, 1991). In the CT-CHEM Module it is designed with the principle of involving students in producing projects related to important concepts in the electrochemistry topic in groups. At the same time cooperative learning can be performed. Cooperative learning has a strong effect on the academic achievement (Johnson \& Johnson, 2013; Johnson, Johnson, \& Smith, 2014; Stevens \& Slavin, 1995) and helps in solving problems (Johnson, Qin, \& Johnson, 1995). Lye and Koh (2014) suggested in the teaching of constructionism theory and problem-based learning environment can encouraged perspectives and computational training.

In the Project-Based Learning (PBL) approach, students are usually given specifications for the desired project and the learning process is more oriented according to the correct procedures (Savery, 2006). The PBL approach also reduces the role of students in determining goals and outcomes to solve problems (Savery, 2006) and is effective for solving problems (Telegina et al., 2019). The PBL approach in the context of this study is the project created by using Scratch for plugged-in and Model (graphics) for unplugged in the electrochemistry topic by focusing on abstract concepts and many misconceptions. Projects created by using Scratch can be shared with one another (Bers, 2018).

The Inquiry-Based Learning (IBL) approach in chemistry is a T\&L that conducts investigations consisting of specific phases with the guidance of teachers. IBL can be divided into four types which are structured, guided, open and coupled (Martin, 2002). In
Table 1. Quasi-experimental design

\begin{tabular}{lccc}
\hline Groups & Pre-test & Intervention & Post-test \\
\hline First treatment & $\mathrm{U}_{1}$ & $\mathrm{X}_{1}$ & $\mathrm{U}_{2}$ \\
Second treatment & $\mathrm{U}_{1}$ & $\mathrm{X}_{2}$ & $\mathrm{U}_{2}$ \\
Control & $\mathrm{U}_{1}$ & $\mathrm{X}_{3}$ & $\mathrm{U}_{2}$ \\
\hline
\end{tabular}

Note

$\mathrm{U}_{1}:$ Pre-test

$\mathrm{U}_{2}:$ Post-test

$\mathrm{X}_{1}$ : CT Module Plugged-in (CTMP)

$\mathrm{X}_{2}:$ CT Module Unplugged and Plugged-in (CTUP)

$\mathrm{X}_{3}$ : Conventional Method $(\mathrm{CM})$

this study, the researchers used the coupled inquiry. The coupled inquiry is a combination of guided and open inquiries (Martin, 2002; Roziah, 2005). The approach in learning begins with the guided inquiry, with the teacher playing a role in triggering questions to stimulate students to continue thinking and making explorations and then the students will prepare procedures and then do the research.

On the basis of the conceptual framework in Figure 1, this study developed following research questions: (1) Are the CTMUP, CTMP and CM teaching approaches effective in increasing achievements in electrochemistry topic? (2) Are there differences in the CTMUP, CTMP and $\mathrm{CM}$ of achievements in the electrochemistry topic based on gender? According to such research questions, the study developed the following two null hypotheses:

$\mathrm{H}_{01}$ : There is no significant difference in the mean score of the electrochemistry topic achievement test between groups following the CTMUP, CTMP and CM teaching approaches.

$\mathrm{H}_{02}$ : There is no significant difference in the mean score of the electrochemistry topic achievement test by gender between groups according to the CTMUP, CTMP and CM teaching approaches.

\section{METHODOLOGY}

\section{Research Design}

In this study, the approach used by the researchers is quasi-experimental design using the pre and the posttest. There are two independent variables which are teaching approaches (three teaching approaches) and gender. There are two treatment groups for the CT Module teaching approach. The first treatment is to integrate plugged-in CT (CTMP). Whilst the second treatment uses CT Module, which combines unplugged and plugged-in activities (CTMUP) as an approach in teaching. The control group is the group that follows the conventional teaching approach $(\mathrm{CM})$. Table 1 shows the summary of the study design.

\section{Study Sample}

In this study, the researchers have employed purposive sampling. Sampling is intended to be applied 
Table 2. Number of participants and types of interventions

\begin{tabular}{llccccc}
\hline \multirow{2}{*}{ Group } & \multirow{2}{*}{ School } & \multicolumn{2}{c}{ Gender } & \multirow{2}{*}{ Total } & \multirow{2}{*}{ Interventions } \\
\cline { 3 - 4 } & & Male & Female & & CTMP \\
First treatment & A & 16 & 15 & 31 & CTMUP \\
Second treatment & $\mathrm{B}$ & 10 & 14 & 24 & CM \\
Control & $\mathrm{C}$ & 14 & 16 & 30 & C \\
\hline
\end{tabular}

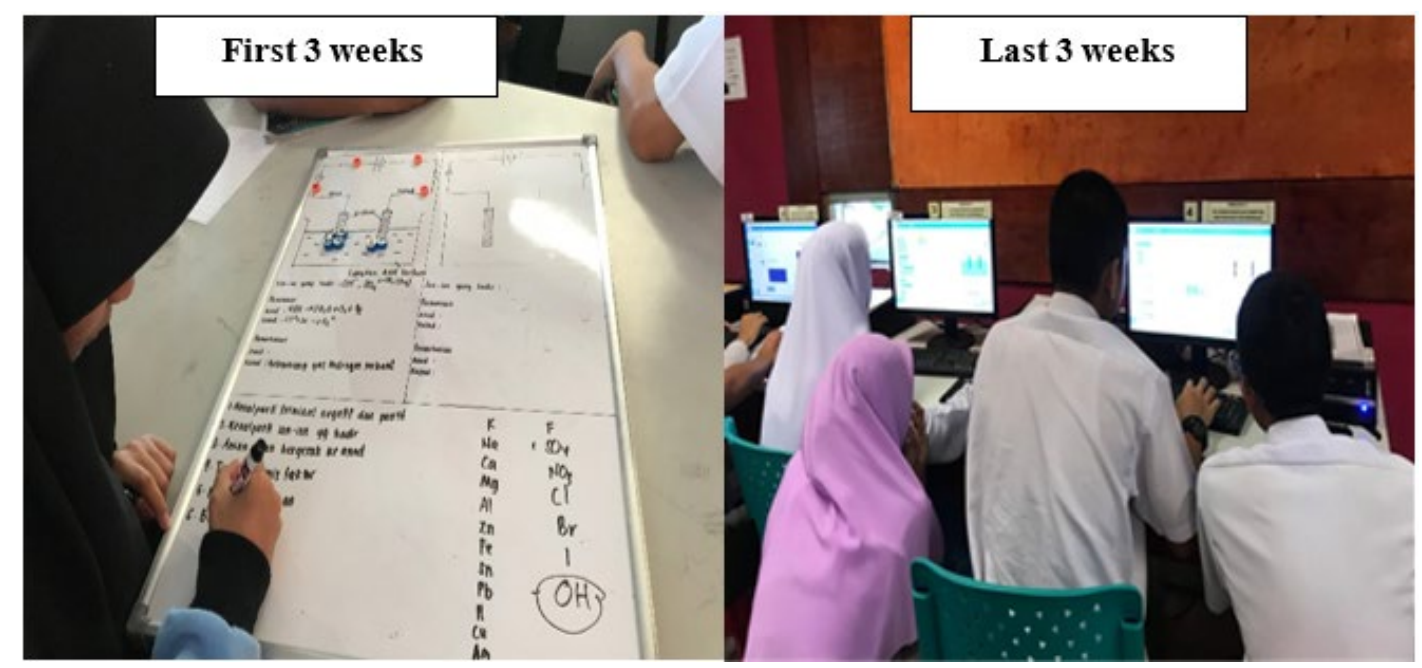

Figure 2. CTMUP approach Group

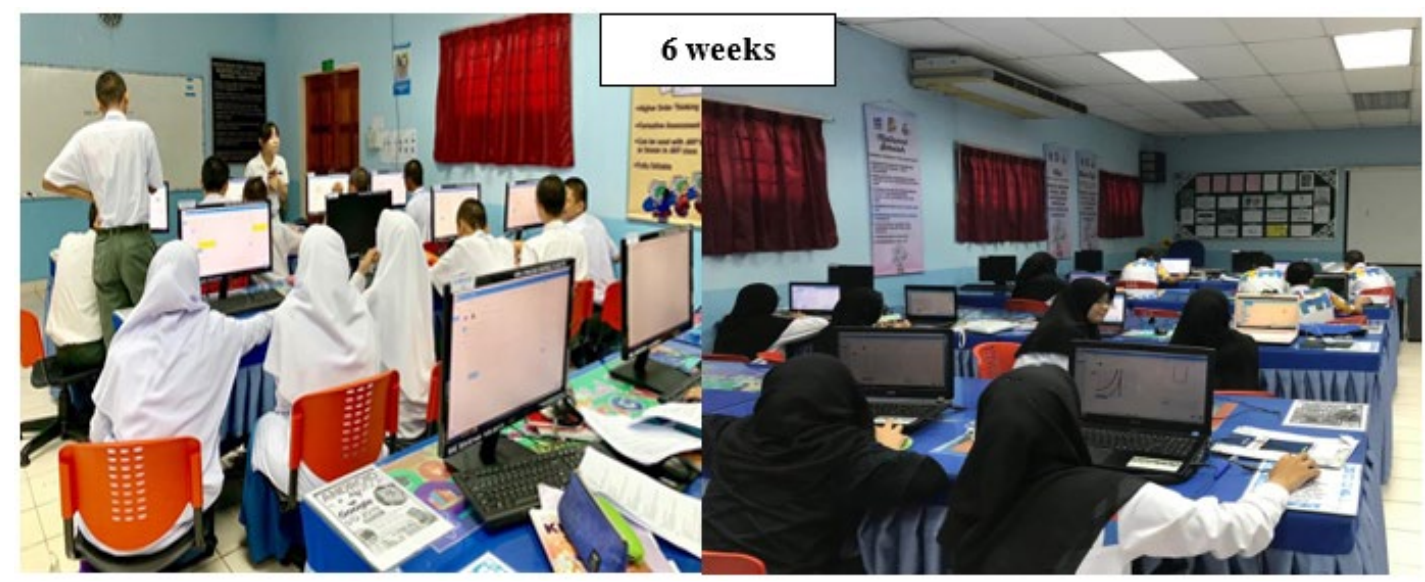

Figure 3. CTMP approach Group

to selected individuals because they have experiences at the centre of the phenomenon (Creswell, 2009). This sampling involves schools in urban areas equipped with computers. The sample of this study involves 85 form four students consisting of $40(47.06 \%)$ male and 45 $(52.94 \%)$ female students aged 16 years old. Three public schools in one of the districts in Malaysia participated. Table 2 exhibits the number of participants and the types of interventions. This study followed the ethical guidelines provided by the Universiti Kebangsaan Malaysia and Ministry of Education Research and Development Division. Proper permissions were obtained from all the respondents and from the schools in which the study was conducted. Additionally, students were also informed that these interventions and tests would be used for research purpose only and would never be seen or used by their teachers.

\section{Procedure}

The interventions used in this study are based on the CT-CHEM Module in the electrochemistry topic. This module consists of two forms of teaching approaches, namely, plugged-in (CTMP) and unplugged + pluggedin (CTMUP). The control group follows the CM teaching approach. The CM approach uses the existing problemsolving approach used by teachers under the Ministry of Education including using computer technology but does not involve programming. This study was conducted in the school on the basis of the normal learning schedule conducted twice a week. Each session takes 70 minutes, and the duration of this intervention is six weeks. Nonetheless, projects produced by students will be completed outside of learning period (informal). The CTMP teaching approach produces three projects, and the CTMUP approach produces two projects by 
Table 3. CT skills in CT-CHEM Module

\begin{tabular}{ll}
\hline CT skills & Explanation \\
\hline Algorithmic thinking & $\begin{array}{l}\text { Involves the use of sequences orderly in the process of problem solving or task completion } \\
\text { (Faber et al., 2017; Yadav, Hong, \& Stephenson, 2016). }\end{array}$ \\
Abstraction & $\begin{array}{l}\text { Eliminating the unrelated aspects of a problem, the individual is undisturbed and can directly } \\
\text { pay attention to the important aspects of the problem (Faber et al., 2017). }\end{array}$ \\
Decomposition & $\begin{array}{l}\text { The way of thinking about an artefact in the context of looking at its components or parts by } \\
\text { performing it into a set of steps (Csizmadia et al., 2015). }\end{array}$ \\
Generalisation/ & $\begin{array}{l}\text { A solution approach found to the problem and can be used or applied to other problems or } \\
\text { pattern recognition } \\
\text { imprlar. Elements from the problem can be used to solve problems in other situations and can be } \\
\text { improved on the basis of the situation (Faber et al., 2017). Identify patterns, and equations and } \\
\text { exploit those characteristics (Csizmadia et al., 2015). } \\
\text { Evaluation is a process that ensures the solution, whether algorithm, system or process, is a good } \\
\text { one and fits the purpose. Various aspects of solutions must be evaluated. Is it correct? Are they } \\
\text { fast enough? (Beecher, 2017; Csizmadia et al., 2015) }\end{array}$ \\
\hline
\end{tabular}

using Scratch 3.0. Produced projects are related to the important concepts in the electrochemistry topic. Before the intervention was conducted, the students and teachers had already been briefed. The teachers were briefed regarding the concept of CT and Scratch 3.0 software, whilst the students were briefed about using the Scratch software for one day. The pre-test was given to the students before the intervention was performed, and the post-test was conducted as soon as the intervention was completed.

In the CT-CHEM Module, five CT skills were integrated into the chemistry subject, and the five skills were employed in solving problems related to the chemistry subject in the CTUMP and CTMP groups. The five CT skills were applied on the basis of the previous studies that have been used by several researchers (Csizmadia et al., 2015; Psycharis \& Kotzampasaki, 2019). Table 3 manifests the explanation for every skill.

Integration of CT skill in electrochemistry topic has been done in plugged-in activity by CTMP group, while CTMUP group combined both unplugged and pluggedin activities. Unplugged activity has only been done from week one until week three. The CT activities for the first week until the third week for CTMP and CTMUP groups have been shown in Figure A1 (Appendix) while the activities for week four have been shown in Figure A2 (Appendix).

On week five until week six, both treatment groups will be given some tasks to create Scratch project. The application of CT skills in chemistry is based on the tasks given to the students in the CTMP and CTMUP groups. Figure A3 (Appendix) shows the application of CT skills for decomposition and algorithmic thinking, Figure A4 (Appendix) depicts the generalisation skills applied in chemistry and Figure A5 (Appendix) illustrates the abstraction and evaluation skills.

\section{Instruments}

The chemistry achievement test consists of 20 objective questions, two structural questions and two essay questions to test knowledge on electrochemistry concept. The total marks for all questions are 80 marks which will be converted to a percentage (100\%) for further analysis. The questions are taken from the actual Malaysian Certificate of Education (SPM) questions from previous years and the states in Malaysia that contain the objective, structural and essay questions. The content items in the achievement test have been reviewed and evaluated by experts of the validity aspect which consists of lecturers and teachers. The time taken to conduct the test was two hours. The achievement tests were administered twice, which involved the pre and post-tests. The pre-test aimed to identify the knowledge of the students before the intervention was conducted, whilst the post-test aimed at evaluating the effectiveness of the modules used compared with the control group in the context of improving their knowledge in the electrochemistry topic. The contents of the pre and posttest items are similar in terms of Bloom Taxonomy level aspects. The reliability of the instrument used is high, the findings show that the correlation between preachievement test scores and post-achievement tests is strong $(\mathrm{r}=0.742, \mathrm{p}<0.01)$. The objective questions in the achievement test, item analysis was conducted after preand post-test in the pilot study for the purpose of seeing the suitability of the question to be accepted, rejected or improved. Item analysis can be determined through difficulty index (DIF) and discrimination index (DI).

\section{Data Analysis}

This study includes two independent variables, namely, the gender and groups, whereas the dependent variable is the chemistry achievement. Three groups represent the three teaching approaches, which are CTMP, CTMUP and CM. The two-way ANCOVA 
Table 4. Levene test for the post-test of chemistry achievement by groups and gender

\begin{tabular}{lccc}
\hline$F$ & $\mathrm{dk} 1$ & $\mathrm{dk} 2$ & $P$ \\
\hline 1.218 & 5 & 79 & 0.309 \\
\hline
\end{tabular}

Significant level $=0.05$

Table 5. Two-way ANCOVA analysis for CT skills across gender

\begin{tabular}{lcccccc}
\hline Effect & Sum of square & $\mathrm{df}$ & Mean square & F & Sig.(p) & Partial eta squared \\
\hline Group & 749.446 & 2 & 374.723 & 3.213 & $\mathbf{0 . 0 4 6}$ & 0.076 \\
Gender & 7.762 & 1 & 7.762 & 0.067 & 0.797 & 0.001 \\
\hline
\end{tabular}

Table 6. Comparison of mean scores for chemistry achievement by groups and gender

\begin{tabular}{llccc}
\hline Group & Gender & $\mathrm{M}$ & $\mathrm{SD}$ & $\mathrm{N}$ \\
\hline Control & Male & 36.714 & 11.255 & 14 \\
$(\mathrm{CM})$ & Female & 46.062 & 8.242 & 16 \\
\hline First treatment & Male & 51.313 & 11.797 & 16 \\
(CTMP) & Female & 47.533 & 12.665 & 15 \\
\hline Second treatment & Male & 45.200 & 6.877 & 10 \\
(CTMUP) & Female & 37.929 & 11.731 & 14 \\
\hline \multirow{2}{*}{ Total } & Male & 44.675 & 12.147 & 40 \\
& Female & 44.022 & 11.506 & 45 \\
\hline
\end{tabular}

analysis conducted aims to differentiate the effectiveness of the three teaching approaches by controlling knowledge of the students as the covariate towards chemistry achievement.

\section{FINDINGS AND DISCUSSION}

The Levene test was conducted to test the homogeneity of the variance in the dependent variable which is the chemistry achievement towards the independent variables (group and gender). Table 4 shows the results of the Levene test.

The Levene test in Table 4 shows that the post-test of student electrochemistry achievement is not significant to the group and gender $[F(5,79)=1.28, p>0.309]$. According to Pallant (2010), the assumption of homogeneity variance is adhered to because the significance value is above 0.05 . Thus, the homogeneity variance requirements are met and the two-way ANCOVA analysis can be continued. Table 5 presents the findings of the two-way ANCOVA analysis.

The findings of two-way ANCOVA analysis showed significant differences in the chemistry achievement and not significant by gender between the three teaching approaches, namely, CM, CTMP and CTMUP.

\section{Comparison of Mean Scores of Chemistry Achievement Tests by Gender}

The findings of the chemistry achievement test by gender are insignificant. The summary in general shows that the chemistry achievement of students in the electrochemistry topic for males and females are almost similar. Nevertheless, the differences in the chemistry achievement of male and female students can be compared on basis of descriptive data. Table 6 shows comparison of the post-test achievement of students in the electrochemistry topic by group and gender, the mean score of male student achievement is higher for the first (CTMP) and second (CTMUP) treatment groups compared with the control group (CM). This indicates that the achievement of male students follows the CTMP $(\mathrm{M}=51.313, \mathrm{SD}=11.797)$, CTMUP $(\mathrm{M}=45.200, \mathrm{SD}=$ 6.877) and $\mathrm{CM}(\mathrm{M}=36.714, \mathrm{SD}=11.255)$ approaches. Table 6 also affirms that the mean score of achievement for female students shows CTMP $(\mathrm{M}=47.533, \mathrm{SD}=$ 12.665), CTMUP $(\mathrm{M}=37.929, \mathrm{SD}=11.731)$ and $\mathrm{CM}(\mathrm{M}=$ 46.062 , SD $=8.242)$. These findings indicate that the achievement of students using the CTMP approach is better compared with the CTMUP and CM. Notwithstanding, the achievement of control students in CM is better than the CTMUP approach. Overall, male students $(M=44.675, \mathrm{SD}=12.147)$ have better chemistry achievement compared with female students $(\mathrm{M}=$ 44.022, SD = 11.506).

\section{Chemistry Achievement in the Electrochemistry Topic}

Table 7 shows the descriptive data comparing the mean scores between the three groups representing the three teaching approaches. Overall, the CTMP teaching approach $(M=48.624)$ has the highest mean value followed by the CTMUP teaching approach $(\mathrm{M}=42.444)$ and $C M(M=41.472)$. The findings confirm that the CTMP approach is more effective in improving the achievement of electrochemistry topic compared with to the CTMUP and CM approaches.

On basis of the results of the analysis in Table 5, it is found that there was a significant group effect $F(2,78)=$ $3.213, \mathrm{p}<0.05$; with a medium size effect (partial eta squared $=0.076$ ). This indicates that there is a significant difference in the post-test scores of electrochemistry achievement between the control group (CM) and the 
Table 7. Comparison of the post-test mean score between groups

\begin{tabular}{lcccc}
\hline \multirow{2}{*}{ Group } & \multirow{2}{*}{$\mathrm{M}$} & Std error & \multicolumn{2}{c}{ Confidence interval (95\%) } \\
\cline { 4 - 5 } Control (CM) & 41.472 & 1.978 & Upper & Lower \\
First treatment (CTMP) & 48.624 & 2.097 & 37.535 & 45.410 \\
Second treatment (CTMUP) & 42.444 & 2.400 & 34.449 & 52.798 \\
\hline
\end{tabular}

Significant level $=0.05$

Table 8. Post hoc test analysis between groups towards chemistry achievement

\begin{tabular}{|c|c|c|c|c|c|c|}
\hline \multirow{2}{*}{ Group (I) } & \multirow{2}{*}{ Group (J) } & \multirow{2}{*}{$\overline{\mathrm{x}}(\mathrm{I}-\mathrm{J})$} & \multirow{2}{*}{ Std. Error } & \multirow{2}{*}{$p$} & \multicolumn{2}{|c|}{ Confidence interval (95\%) } \\
\hline & & & & & Upper & Lower \\
\hline \multirow{2}{*}{ 1.CM } & 2. CTMP & -7.151 & 2.905 & 0.048 & -14.260 & -0.043 \\
\hline & 3.CTMUP & -0.971 & 3.087 & 1.000 & -8.523 & 6.581 \\
\hline \multirow{2}{*}{ 2.CTMP } & 1.CM & 7.151 & 2.905 & 0.048 & 0.043 & 14.260 \\
\hline & 2.CTMUP & 6.180 & 3.398 & 0.218 & -2.134 & 14.494 \\
\hline \multirow{2}{*}{ 3.CTMUP } & 1.CM & 0.971 & 3.087 & 1.000 & -6.581 & 8.523 \\
\hline & 2.CTMP & -6.180 & 3.398 & 0.218 & -14.494 & 2.134 \\
\hline
\end{tabular}

Significant level $=0.05$

treatment group one (CTMP) and the treatment group two (CTMUP). The post hoc comparison using the Bonferroni test in Table 8 shows that there is a significant difference in the mean score of the electrochemistry achievement of the students between the CM and CTMP groups $[\Delta \mathrm{M}=-7.151, \mathrm{p}=0.048$ and $\mathrm{p}<0.05]$. The comparison between the CM group with the CTMUP group $[\Delta \mathrm{M}=-0.971, \mathrm{p}=1.00$ and $\mathrm{p}>0.05]$ and the CTMP group with the CTMUP group $(\Delta \mathrm{M}=6.180, \mathrm{p}=0.218$ and $\mathrm{p}>0.05$ ] did not show significant differences.

The analysis from the post hoc test in Table 8 found that UPPE achievement scores increased when the students were involved with the CT-CHEM Module intervention. Therefore, students involved in T\&L activities using the CT-CHEM Module for the CTMP approach, improved the achievement of electrochemistry topic compared with the CTMUP and $\mathrm{CM}$ approaches. The evident approach out of the three is the CTMP approach which involved the students with Scratch programming activities with more time to produce projects than the CTMUP approach. The CTCHEM Module uses the IBL and PBL approaches, encouraging students to think critically, and creatively and to solve problems (Mannila et al., 2014). The PBL and IBL approaches based on scaffolding with the guidance of peers and teachers in the Zone of Proximal Development enable students to solve a variety of more complex problems (Basawapatna et al., 2013). PBL provides an opportunity for students to work in groups to perform activities on a hands-on basis to stimulate them to build concepts (Bicer et al., 2015) that are abstract and have many misconceptions in the electrochemistry topic (Garnett \& Treagust, 1992a, 1992b). The higher number of projects produced in CTMP enables students to better understand abstract concepts in chemistry. These concepts are particularly at the microscopic level i.e., ion and electron flow and the symbolic level of chemical formulas and equations (Kamisah \& Lee, 2013).
Plugged-in CT skills are able to relate to the real world (French Academy of Sciences, 2013) and daily life (Voogt et al., 2015) making learning more effective than conventional methods.

The findings of this study confirm that the CTMP approach is effective in improving the achievement of electrochemistry topic compared to the CTMUP and CM approaches. The CTMP approach is the most distinct out of the three approaches involving the students with Scratch programming activities with more time to produce projects. The findings of the study are also supported by the previous studies have proved that plugged-in activities (Scratch) can help in solving problems amongst students in understanding a concept (Kalelioğlu \& Gülbahar, 2014; Moreno-León, Robles, \& González, 2015; Su et al., 2014) and improving achievements (Basu, Biswas, \& Kinnebrew, 2017; Rodriguez, Rader, \& Camp, 2016). Gambari et al. (2016) also proved that learning using computers has been able to improve achievements in chemistry subject.

CT activities through the projects produced by students provide an opportunity for them to visualise important and abstract concepts in the electrochemistry topic. This approach provides students with the experience of using three levels of representation, which are macroscopic, submicroscopic and symbolic. The triplet model is a key model used in chemistry education in demonstrating relationships (macro, micro and symbolic) (Gilbert \& Treagust, 2009) in improving students' understanding of students electrochemistry. The macroscopic stage is the physical representation level through observations that can be seen through physical experiments, whilst the submicroscopic stage occurs through the project produced as in Figure 4. At this stage, students can see the types of ions present in the solution called $\mathrm{Cu}^{2+}, \mathrm{H}^{+}, \mathrm{OH}^{-}$and $\mathrm{SO}^{2-}$, the movement of electrons from anode to cathode and changes from atoms to ions (ionisation). Figure 5 depicts 


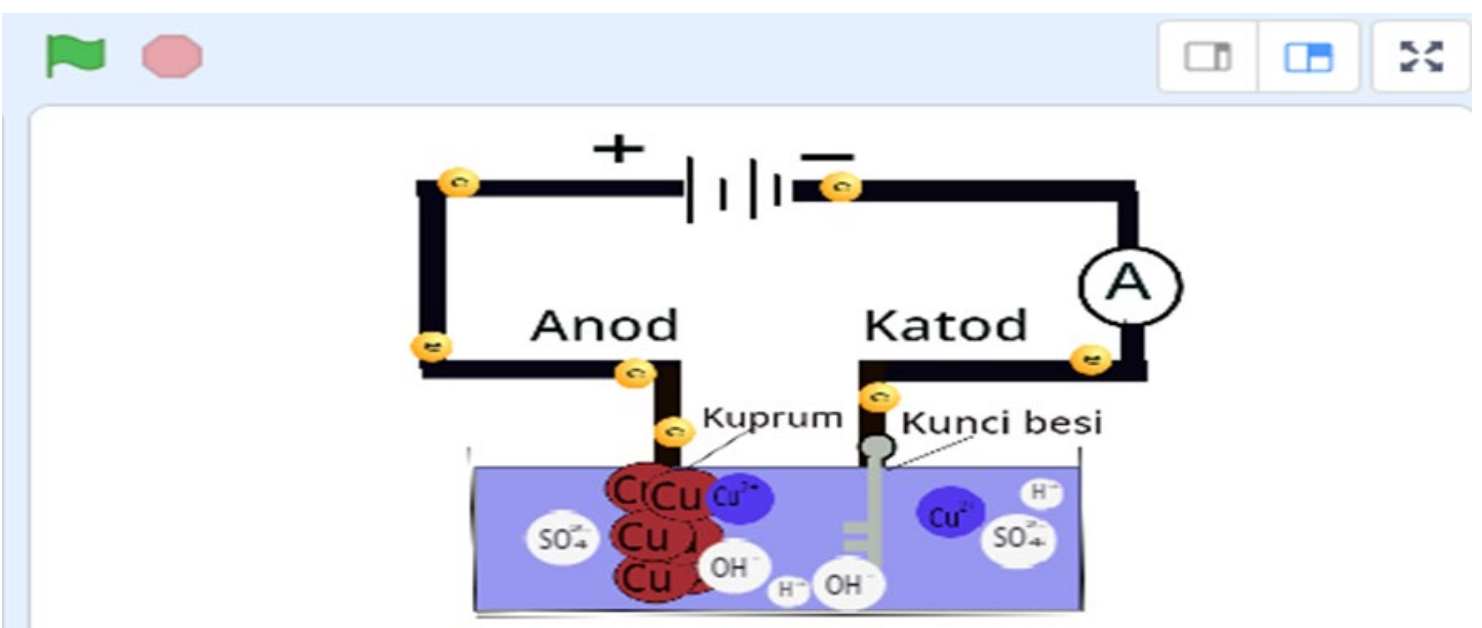

Figure 4. Observation at the Initial Stage of the project

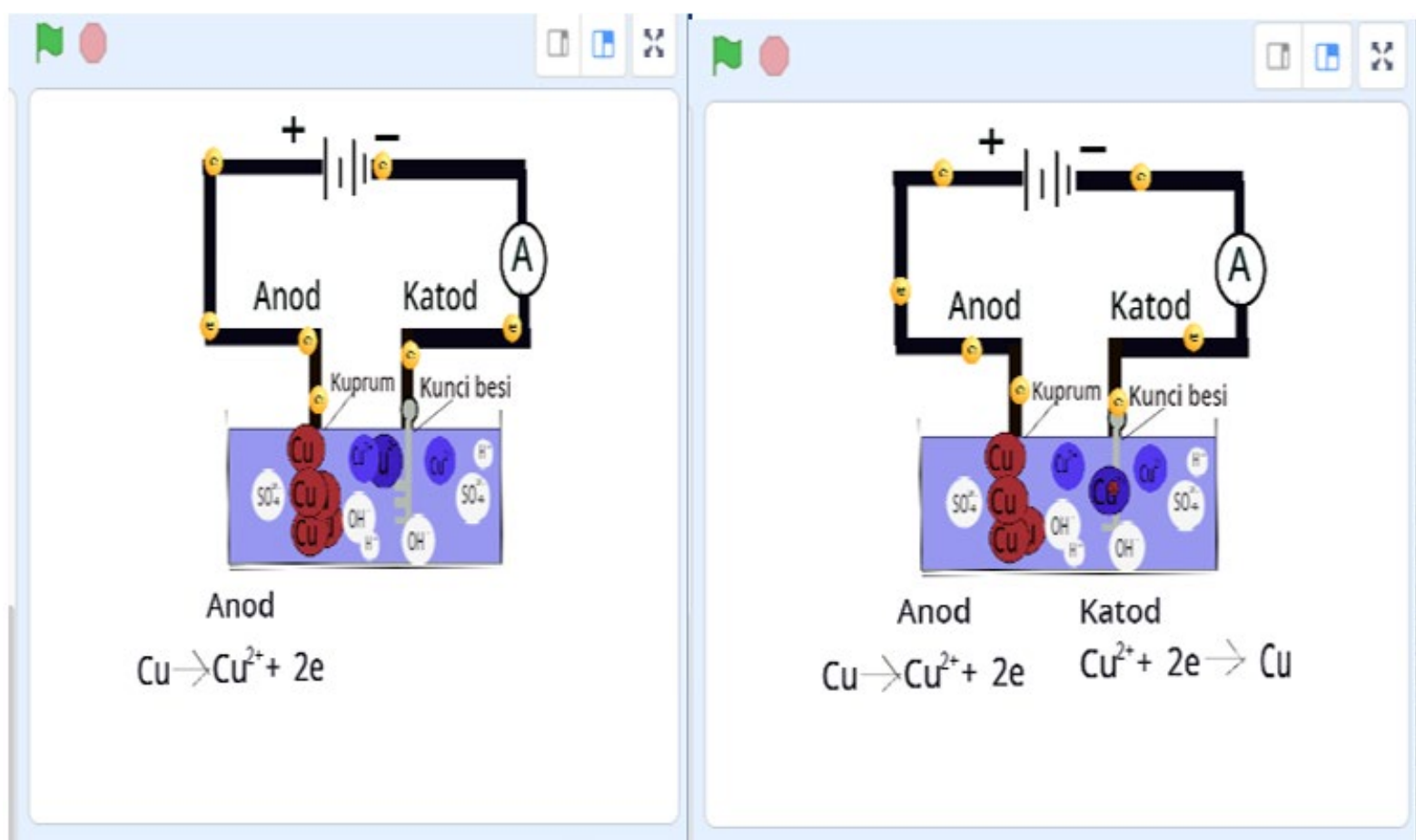

Figure 5. Observation at the Middle Stage of the Project

the symbolic stage through the equations made by the students This equation represents the result of observations through animation on how the process of ionisation at the anode and discharge at the cathode occurs.

In the middle stage of the project, students can observe how the copper atoms release two electrons to form copper ions $\left(\mathrm{Cu}^{2+}\right)$ and then when they are at the cathode the copper ions will receive two electrons to form copper atoms $(\mathrm{Cu})$ as in Figure 5. The process of electrolysis shown through photos used by the students will be able to help them understand the reaction significantly (Chang 2010). The use of computer technology such as Scratch can help students in understanding abstract concepts. The development and used of sophisticated technology have provided a better approach to things that are invisible to the naked eye (Chang, 2010) through computer technology.

As a result of students' observations in electrolysis, students can express their observations through the observations at the initial stage of Figure 4, the middle in Figure 5 and the end of the project in Figure 6 clearly. 


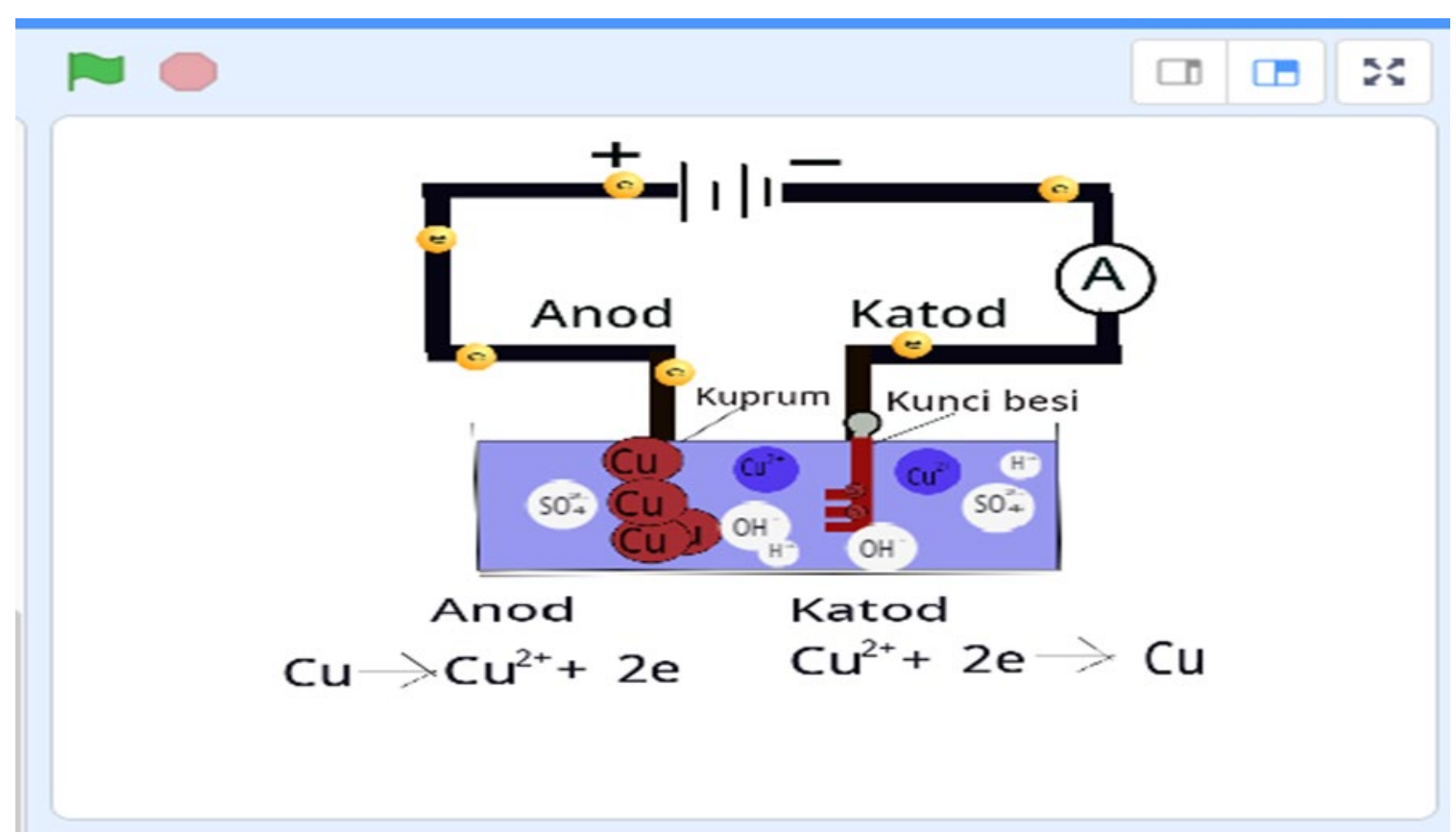

Figure 6. Observation at the End of the Project

Table 9. Observation and explanation from the project of the students

\begin{tabular}{ll}
\hline Observation & Explanation \\
\hline - Colour of solution unchanged & $\begin{array}{l}\text { The number of copper ion before and after the } \\
\text { experiment remains similar }\end{array}$ \\
$\begin{array}{ll}\text { - Electrode at the cathode thickening and thinning at } \\
\text { anode }\end{array}$ & $\begin{array}{l}\text { Electrode at the anode thinning (copper atom released } \\
\text { two electrons to form copper ions) }\end{array}$ \\
- Brown colour deposited at the cathode & $\begin{array}{l}\text { Electrode at the cathode thickening (copper ion received } \\
\text { two electrons to form copper atom) }\end{array}$ \\
\hline
\end{tabular}

Observations in this electrolysis process can be understood by students through explanation from the projects produced by students. Table 9 presents the observations and explanations.

Although there is no significant difference between CTMUP and CM, the mean score of the CTMUP achievement score is higher than CM. Amongst the factors is that the electrochemistry topic requires students to understand abstract concepts (Levy Nahum et al., 2004). Therefore, it is difficult for students to visualise abstract concepts through unplugged. Although students in the CTMUP approach used computers in producing projects, the three weeks given is less than the CTMP approach which has been given six weeks. Kalelioğlu and Gülbahar (2014) argued that Scratch programming did not show significant differences in problem solving due to short time implementation factors. In the context of this study, the CTMUP group only conducted plugged-in activities for three weeks compared with six weeks for the CTMP group. In addition, the CTMUP group only performed two projects compared with three projects for the CTMP group.

The use of existing materials such as magnetic board (CTMUP) and project production through animation (CTMUP and CTMP), can help students to visualise abstract concepts in electrochemistry. Students are given the opportunity build their own visualisation of the algorithm (Hundhausen, Douglas, \& Stasko, 2002). To understand the concept of chemistry, students must connect new and existing concepts (Gulacar, Milkey, \& Mclane, 2019) through visualisation. The production of projects produced by students (CTMUP and CTMP) is more effective than $\mathrm{CM}$ to understand electrochemistry. The strength of the CT-CHEM Module is that it combines approaches, PBL and IBL. According to Telegina et al. (2019), PBL by mini projects in teaching is effective for solving difficult to understand problems. Combination of IBL and engineering design, productive to a teacher educator and support provider of science teachers (Shirey, 2017) and CT skills have given support to engineering design in problem solving. Therefore, CT is an ability that considered essential for the process of problem solving in every science (Psycharis \& Kotzampasaki, 2019) especially in chemistry.

\section{CONCLUSION}

The CT-CHEM Module promotes CT skills through two teaching approaches (CTMP and CTMUP) in improving the understanding of the electrochemistry topic. Both of these approaches are also supported by the PBL and IBL learning throughout this study. The 
activities in the CT-CHEM Module provide students with the opportunity to understand essential concepts and solve problems in the electrochemistry topic by producing projects using Scratch. This study proved that applying plugged-in CT skills is more effective in improving the understanding of students of the electrochemistry topic. An important implication in this study is that in the process of understanding important concepts in chemistry, a plugged-in activity approach should be given priority in integrating CT skills. CT integration must be incorporated with all the topics in the chemistry subject and more projects-based created. Therefore, more research should be done on other topics in chemistry, especially those that involve abstract and basic topics so that more students will be interested in chemistry and will venture into the STEM field. Although the main focus is plugged-in, unplugged activities should also be implemented in schools, especially activities outside the classroom. This is because, unplugged and plugged-in activities can clearly improve the chemistry performance and the ability in solving problems.

Author contributions: All authors have sufficiently contributed to the study, and agreed with the results and conclusions.

Funding: This work was supported by the Universiti Kebangsaan Malaysia (GG-2019-007).

Declaration of interest: No conflict of interest is declared by authors.

Acknowledgements: The authors would like to express special words of thanks and their acknowledgment to the Ministry of Education, Malaysia and Faculty of Education, Universiti Kebangsaan Malaysia.

\section{REFERENCES}

Adesoji, F. A, \& Omilani, N. A. (2012). A Comparison of Secondary Schools Students' Levels of Conception of Qualitative and Quantitative Inorganic Analysis. American Journal of Scientific and Industrial Research, $3(2), 56-61$.

Adesoji, F. A., Omilani, N. A., \& Dada, S. O. (2017). A Comparison of Perceived and Actual; Students' Learning Difficulties in Physical Chemistry. International Journal of Brain and Cognitive Sciences, 6(1), 1-8.

Alice, K., et al. (2008). Teori Kognitif Dan Implikasi Dalam Pengajaran Dan Pembelajaran [Cognitive Theory and Implications in Teaching and Learning]. In A. M. Yosof, et al. (Eds.), Pengetahuan Pedagogi Guru (pp. 101-1013). Kuala Lumpur: Universiti Malaysia Sabah.

Barr, D., Harrison, J., \& Conery, L. (2011). Computational Thinking: A Digital Age Skill for Everyone. Learning and Leading with Technology, 38(6), 20-23.

Barr, V., \& Stephenson, C. (2011). Bringing Computational Thinking to K-12: What Is Involved and What Is the Role of the Computer Science
Education Community? ACM Inroads, 2(1), 48-54. https:// doi.org/10.1145/1929887.1929905

Basawapatna, A., Repenning, A., Koh, K. H., \& Nickerson, H. (2013). The Zones of Proximal Flow: Guiding Students Through a Space of Computational Thinking Skills and Challenges. In ICER '13: Proceedings of the ninth annual international ACM conference on International computing education research (pp. 67-74). https://doi.org/10.1145/ 2493394.2493404

Basu, S., Biswas, G., \& Kinnebrew, J. S. (2017). Learner Modeling for Adaptive Scaffolding in a Computational Thinking-Based Science Learning Environment. User Modeling and User-Adapted Interaction, 27(1), 5-53.

Beecher, K. (2017). Computational Thinking: A Beginner's Guide to Problem Solving and Programming. United Kingdom: BCS Learning \& Development Ltd.

Bers, M. U. (2018). Coding and Computational Thinking in Early Childhood: The Impact of ScratchJr in Europe. European Journal of STEM Education, 3(3), 8.

Bers, M. U., Flannery, L., Kazakoff, E. R., \& Sullivan, A. (2014). Computational Thinking and Tinkering: Exploration of an Early Childhood Robotics Curriculum. Computer \& Education, 72, 145-157.

Bicer, A., et al. (2015). STEM Schools vs. Non-STEM Schools: Comparing Students' Mathematics Growth Rate on High-Stakes Test Performance. International Journal on New Trends in Education and Their Implications, 6(1), 138-150.

Brackmann, C. P., et al. (2017). Development of Computational Thinking Skills through Unplugged Activities in Primary School. In WiPSCE 17: Proceedings of the 12th Workshop on Primary and Secondary Computing Education (pp. 6572).

Brand, B. R. (2020). Integrating Science and Engineering Practices: Outcomes from a Collaborative Professional Development. International Journal of STEM Education, 7(1), 13. https://doi.org/ 10.1186/ s40594-020-00210-x

Chang, R. (2010). Chemistry (10th ed.). Boston: McGraw Hill Higher Education.

Creswell, J. W. (2009). Research Design: Qualitative, Quantitative and Mixed Methods Approaches (3rd Ed.). Los Angeles: Sage Publication, Inc.

Csizmadia, A., et al. (2015). Computational Thinking: A Guide for Teachers. United Kingdom: Computing At School.

Curzon, P., McOwan, P. W., Cutts, Q. I., \& Bell, T. (2009). Enthusing \& Inspiring with Reusable Kinaesthetic Activities. In Proceedings of the Conference on Integrating Technology into Computer Science Education, ITiCSE (pp. 94-98). 
Faber, H. H., Wierdsma, M. D. M., Doornbos, R. P., \& Van der Ven, J. S. (2017). Teaching Computational Thinking to Primary School Students via Unplugged Programming Lessons. Journal of the European Teacher Education Network, 12, 13-24.

Farhana, F., \& Khan, F. (2020). Hanya 19 Peratus Pilih Aliran Sains [Only 19 Percent Select Science Stream]. Berita Harian.

Fouh, E., Akbar, M., \& Shaffer, C. A. (2012). The Role of Visualization in Computer Science Education. Computer in the school, 29(1-2), 95-117.

French Academy of Sciences. (2013). Teaching Computer Science in France.Tomorrow Can't Wait -. Retrieved from http://www.academie-sciences.fr/pdf/rap port/rads_0513gb.pdf

Gambari, I. A., Gbodi, B. E., Olakanmi, E. U., \& Abalaka, E. N. (2016). 7 Contemporary educational technology Promoting Intrinsic and Extrinsic Motivation among Chemistry Students Using Computer-Assisted Instruction. Retrieved from https:/ / files.eric.ed.gov/fulltext/EJ1105762.pdf

Gao, X., Li, P., Shen, J., \& Sun, H. (2020). Reviewing Assessment of Student Learning in Interdisciplinary STEM Education. International Journal of STEM Education, 7(24), 1-14.

García Peñalvo, G., et al. (2016). An Overview of the Most Relevant Literature on Coding and Computational Thinking with Emphasis on the Relevant Issues for Teachers. Belgium: TACCLE3 Consortium. Retrieved from https://repositorio.grial.eu/ bitstream/grial/688/1/TACCLE3O5Literaturerev iew-final.pdf

Garnett, P. J., \& Treagust, D. F. (1992a). Conceptual Difficulties Experienced by Senior High School Students of Electrochemistry: Electric Circuits and Oxidation- Reduction Equations. Journal of Research in Science Teaching, 29(2), 121-142. https:/ / doi.org/10.1002/tea.3660290204

Garnett, P. J., \& Treagust, D. F. (1992b). Conceptual Difficulties Experienced by Senior High School Students of Electrochemistry: Electrochemical (Galvanic) and Electrolytic Cells. Journal of Research in Science Teaching, 29(10), 1079-1099.

Gilbert, J.K. \& Treagust, D.F. 2009. Introduction: Macro, submicro and symbolic representations and the relationship between them: Key models in chemical education. In J. K. Gilberth \& D. Treagust (eds.). Multiple Representations in Chemical Education (Vol. 4 pp. 1-10). Netherland: Springer. https:/ / doi.org/10.1007/978-1-4020-8872-8_9

Grover, S., \& Pea, R. (2013). Computational Thinking in K-12: A Review of the State of the Field. Educational Researcher, 42(1), 38-43. https://doi.org/10.3102/ 0013189X12463051
Gulacar, O., \& Bowman, C. R. (2014). Determining What Our Students Need Most: Exploring Student Perceptions and Comparing Difficulty Ratings of Students and Faculty. Chemistry Education Research and Practice, 15, 587-593. https:/ / doi.org/10.1039/ C4RP00055B

Gulacar, O., Milkey, A., \& McLane, S. (2019). Exploring the Effect of Prior Knowledge and Gender on Undergraduate Students' Knowledge Structures in Chemistry. Eurasia Journal of Mathematics, Science and Technology Education, 15(8), em1726. https://doi.org/10.29333/ejmste/106231

Halimaton, H. (2017). Kongres Kebangsaan STEM. Towards Dignifying National Science And Technology.

Haseski, H. I., Ilic, U., \& Tugtekin, U. (2018). Defining a New 21st Century Skill-Computational Thinking: Concepts and Trends. International Education Studies, 11(4), 29. http://www.ccsenet.org/ journal/index.php/ies/article/view/71730

Hundhausen, C. D., Douglas, S. A., \& Stasko, J. T. (2002). A Meta-Study of Algorithm Visualization Effectiveness. Journal of Visual Languages and Computing, (13), 259-290.

ISTE, \& CSTA. 2011. Computational Thinking: Teacher Resources (2nd Ed.). Retrieved from http:/ / www.iste.org/docs/ct-documents/ctleadershipt-toolkit.pdf?sfvrsn=4

Johnson, D. W., \& Johnson, R. T. (2013). The Impact of Cooperative, Competitive, and Individualistic Learning Environments on Academic Achievement. In J. Hattie, \& E. Anderman (Eds.), International handbook of student achievement.

Johnson, D. W., Johnson, R. T., \& Smith, K. A. (2014). Cooperative Learning: Improving University Instruction by Basing Practice on Validated Theory. Journal on Excellence in College Teaching, 25(3\&4), 85118.

Johnson, D. W., Qin, Z., \& Johnson, R. T. (1995). Cooperative versus Competitive Efforts and Problem Solving. American Educational Research Association and SAGE, 65(2), 129-143.

Jong, O. D., \& Treagust, D. F. (2002). The Teaching and Learning of Electtrochemistry. In J. K. Gilbert et al. (Eds.), Chemical Education: Towards Research-Based Practice (pp.317-337). New York: Kluwer Academic Publishers.

Kalelioğlu, F., \& Gülbahar, Y. (2014). The Effects of Teaching Programming via Scratch on Problem Solving Skills: A Discussion from Learners' Perspective. Informatics in Education, 13(1), 33-50.

Kalogiannakis, M., \& Papadakis, S. (2017). Pre-service kindergarten teachers acceptance of "scratchj" as a tool for learning and teaching computational thinking and science education. Retrieved from https://keynote. 
conference-services.net/resources/444/5233/pdf/ ESERA2017_0526_paper.pdf

Kamisah, O., \& Lay, A. N. (2020). MyKimDG Module: An Interactive Platform towards Development of Twenty-First Century Skills and Improvement of Students' Knowledge in Chemistry. Interactive Learning Environments, 1-14. Published online: 26 Feb 2020. https:// doi.org/10.1080/10494820.2020. 1729208

Kamisah, O., \& Lee, T. T. (2013). Impact of Interactive Multimedia Module with Pedagogical Agents on Students' Understanding and Motivation in the Learning of Electrochemistry. International Journal of Science and Mathematics Education, 12(2), 395-421.

Lambert, L., \& Guiffre, H. (2009). Computer Science Outreach in an Elementary School. Journal of Computing Sciences in Colleges, 24(3), 118-124.

Lay, A. N., \& Kamisah, O. (2017). Developing 21st Century Skills through a ConstructivistConstructionist Learning Environment. K-12 STEM Education, 3(2), 205-216.

Leon, J. M., \& Robles, G. (2015). Analyze Your Scratch Projects with Dr. Scratch and Assess Your Computational Thinking Skills. Retrieved from http://jemole.me/replication/2015scratch/InferC T.pdf

Levy Nahum, T., Hofstein, A., Mamlok-Naaman, R., \& Bar-Dov, Z. (2004). Research report (empirical study) can final examinations amplify students' misconceptions in chemistry? Chemistry education: research and practice, 5(3), 301-325.

Lye, S. Y., \& Koh, J. H. L. (2014). Review on Teaching and Learning of Computational Thinking through Programming: What Is next for K-12? Computers in Human Behavior, 41, 51-61. https://doi.org/ 10.1016/j.chb.2014.09.012

Maloney, J., et al. (2010). The Scratch Programming Language and Environment. ACM Transactions on Computing Education, 10(4), 16. https://doi.org/ $10.1145 / 1868358.1868363$

Mann, A., \& DiPrete, T. A. (2013). Trends in Gender Segregation in the Choice of Science and Engineering Majors. Social Science Research, 42(6), 1519-1541.

https:// doi.org/10.1016/j.ssresearch.2013.07.002

Mannila, L., Dagiene, V., Demo, B., \& Settle, A. (2014). Computational Thinking in K-9 Education. In ITiCSE-WGR '14: Proceedings of the Working Group Reports of the 2014 on Innovation \& Technology in Computer Science Education Conference (pp. 1-29). https:// doi.org/10.1145/2713609.2713610

Martin, L. (2002). Defining Inquiry: Exploring the Many Types of Inquiry in the Science Classroom. The Science Teacher, 69, 34-37.
Mellström, U. (2009). The Intersection of Gender, Race and Cultural Boundaries, or Why Is Computer Science in Malaysia Dominated by Women? Social Studies of Science, 39(6), 885-907.

Meng, C. C., Idris, N., \& Eu, L. K. (2014). Secondary Students' Perceptions of Assessments in Science, Technology, Engineering, and Mathematics (STEM). Eurasia Journal of Mathematics, Science and Technology Education, 10(3), 219-227. https:/ / doi.org/10.12973/ eurasia.2014.1070a

Ministry of Education (MOE). (2012). Integrated Curriculum for Secondary Schools Curriculum: Specifications Chemistry Form 4. Putrajaya: Curriculum Development Centre.

Ministry of Education (MOE). (2016a). Basics Computer Science: Standard Curriculum and Assessment Document. Putrajaya.

Ministry of Education (MOE). (2016b). PISA 2015: Programme for International Student Assesment. Putrajaya: Educational Planning and Research Division (EPRD).

Moreno-León, J., Robles, G., \& González, M. R. (2015). Dr. Scratch: Automatic Analysis of Scratch Projects to Assess and Foster Computational Thinking. RED-Revista de Educación a Distancia. Número, 46, 123.

Nelson, T. H., et al. (2015). Supporting Middle School Teachers' Implementation of STEM Design Challenges. School Science and Mathematics, 116(4), 177-188.

Novrita Mulya, R. (2012). Pengaruh Sikap Pada Mata Pelajaran Kimia Dan Konsep Diri Terhadap Prestasi Belajar Kimia. Jurnal Formatif, 2(3), 218-226.

Olabe, J. C., et al. (2014). Solving Math and Science Problems in the Real World with a Computational Mind. New approaches in education research, 3(2), 7582.

Orlich, D., et al. (2010). Teaching Trategies: A Guide to Effective Instruction (9th Ed.). Australia: Wadsworth Cengage Learning.

Papadakis, S. J., Kalogiannakis, M., Zaranis, N., \& Papadakis, S. (2016). Developing Fundamental Programming Concepts and Computational Thinking with ScratchJr in Preschool Education: A Case Study. International Journal of Mobile Learning and Organisation, 10(3), 187-202.

Papert, S., \& Harel, I. (1991). Situating constructionism. In S. Papert \& I. Harel (Eds.), Constructionism. Ablex Publishing Corporation.

Pellegrino, J. W., \& Hilton, M. L. (2012). Education for Life and Work: Developing Transferable Knowledge and Skills in the 21 St Century. Washington, USA: The National Academies of Press. 
Psycharis, S. (2018). Steam in Education: A Literature Review on the Role of Computational Thinking, Engineering Epistemology and Computational Science. Computational STEAM Pedagogy (Csp). S. Psycharis Scientific Culture, 4(2), 51-72.

Psycharis, S., \& Kotzampasaki, E. (2019). The Impact of a STEM Inquiry Game Learning Scenario on Computational Thinking and Computer Selfconfidence. Eurasia Journal of Mathematics, Science and Technology Education, 15(4), em1689. https://doi.org/10.29333/ejmste/103071

Qin, H. (2009). Teaching Computational Thinking through Bioinformatics to Biology Students. In SIGCSE'09 - Proceedings of the 40th ACM Technical Symposium on Computer Science Education (pp. 188191).

Reddy, L. (2020). An Evaluation of Undergraduate South African Physics Students' Epistemological Beliefs When Solving Physics Problems. Eurasia Journal of Mathematics, Science and Technology Education, 16(5), em1844. https:// doi.org/10.29333/ejmste/7802

Reichert, J. T., Couto Barone, D. A., \& Kist, M. (2020). Computational Thinking in K-12: An analysis with Mathematics Teachers. Eurasia Journal of Mathematics, Science and Technology Education, 16(6), em1847. https:// doi.org/10.29333/ ejmste/7832

Resnick, M., Maloney, J., Monroy-Hernández, A., Rusk, N., Eastmond, E., Brennan, K., Millner, A., Rosenbaum, E., Silver, J., Silverman, B. \& Kafai, Y. (2009). Scratch: Programming for all. Communications of the ACM, 52(11), 60-67.

Rodriguez, B., Kennicutt, S., Rader, C., \& Camp, T. (2017). Assessing Computational Thinking in CS Unplugged Activities. In Proceedings of the 2017 ACM SIGCSE Technical Symposium on Computer Science Education - SIGCSE '17 (pp. 501-506). New York, New York, USA: ACM Press.

Rodriguez, B., Rader, C., \& Camp, T. (2016). Using Student Performance to Assess CS Unplugged Activities in a Classroom Environment. In ITiCSE '16: Proceedings of the 2016 ACM Conference on Innovation and Technology in Computer Science Education (pp. 95-100). https://doi.org/10.1145/ 2899415.2899465

Roziah, A. (2005). Pembangunan Dan Keberkesanan Pakej Multimedia Kemahiran Berfikir Bagi Mata Pelajaran Kimia [Development and Effectiveness of Thinking Skills Multimedia Package for Chemistry Subjects] (PhD Thesis), Universiti Kebangsaan Malaysia.

Rubiah, M. (2016). Implementation of Problem Based Learning Model in Concept Learning Mushroom as a Result of Student Learning Improvement Efforts Guidelines for Teachers. Journal of Education and Practice, 7(22), 26-30.
Salihuddin, Md S., et al. (2016). Enhancing Student's Higher Order Thinking Skills (HOTS) through the Socratic Method Approach with Technology. In 1st ICRIL-International Conference on Innovation in Science and Technology, Kuala Lumpur: Universiti Teknologi Malaysia, Kuala.

Saltan, F., \& Kara, M. (2016). ICT Teachers' Acceptance of "Scratch" as Algorithm Visualization Software. Higher Education Studies, 6(4), 146-155. https:/ / doi.org/10.5539/hes.v6n4p146

Samri, C., Kamisah, O., \& Anuar, N. N. (2020). Level of Computational Thinking Skills among Secondary Science Student: Variation across Gender and Mathematics Achievement. International Council of Association for Science Education, 31(2), 159-163.

Savery, J. R. (2006). Overview of Problem-Based Learning: Definitions and Distinctions. The Interdisciplinary Journal of Problem-based Learning, 1(1), 9-20.

Schmidth, H.-J., Marohn, A., \& Harrison, A. G. (2007). Factors That Prevent Learning in Electrochemistry. Journal of Research in Science Teaching, 44(2), 258-283.

Schunk, D. H. (2012). Learning Theories an Educational Perspective (6th ed.). Boston: Pearson Education.

Shakhman, L., \& Barak, M. (2019). The Physics ProblemSolving Taxonomy (PPST): Development and Application for Evaluating Student Learning. Eurasia Journal of Mathematics, Science and Technology Education, 15(11), em1764. https:/ / doi.org/10.29333/ejmste/109266

Shirey, K. L. (2017). Teacher Productive Resources for Engineering Design Integration in High School Physics Nstruction (Fundamental). In Proceedings of the 2017 ASEE Annual Conference, Columbus.

Shute, V. J., Sun, C., \& Clarke, J. A. (2017). Demystifying Computational Thinking. Educational Research Review, 22, 142-158. https://doi.org/10.1016/ j.edurev.2017.09.003

Smit, K., De Brabander, C. J., \& Martens, R. L. (2016). Scandinavian Journal of Educational Research Student-Centred and Teacher-Centred Learning Environment in Pre-Vocational Secondary Education: Psychological Needs, and Motivation. Scandinavian Journal of Educational Research, 58(6), 695-712.

Smith, S., \& Burrow, L. E. (2016). Programming Multimedia Stories in Scratch to Integrate Computational Thinking and Writing with Elementary Students. Journal of Mathematics Education, 9(2), 119-131.

Sridaran, R., \& Shailaja, J. (2015). Computational Thinking, the Intellectual Thinking for the 21st Century. International Journal of Advanced Networking Applications (IJANA), 39-46. 
Stevens, R. J., \& Slavin, R. E. (1995). The Cooperative Elementary School: Effects on Students' Achievement, Attitudes, and Social Relations. American Educational Research Journal, 32(2), 321351. https:// doi.org/10.3102/00028312032002321

Su, A. Y. S., et al. (2014). Investigating the Role of Computer-Supported Annotation in ProblemSolving-Based Teaching: An Empirical Study of a Scratch Programming Pedagogy. British Journal of Educational Technology, 45(4), 647-665.

Sustekova, E., Kubiatko, M., \& Usak, M. (2019). Validation of Critical Thinking Test on Slovak Conditions. Eurasia Journal of Mathematics, Science and Technology Education, 15(12), em1798. https:/ / doi.org/10.29333/ejmste/112295

Swaid, S. I. (2015). Bringing Computational Thinking to STEM Education. Procedia Manufacturing, 3, 36573662.

https:/ / doi.org/10.1016/j.promfg.2015.07.761

Tanujaya, B., Mumu, J., \& Margono, G. (2017). The Relationship between Higher Order Thinking Skills and Academic Performance of Student in Mathematics Instruction. International Education Studies, 10(11), 78.

Telegina, N. V., Drovosekov, S. E., Vasbieva, D. G., \& Zakharova, V. L. (2019). The Use of Project Activity in Teaching Mathematics. Eurasia Journal of Mathematics, Science and Technology Education, 15(8), em1738. https://doi.org/10.29333/ejmste/108439

Thies, R., \& Vahrenhold, J. (2013). On Plugging 'Unplugged' into CS Classes. In SIGCSE 2013 Proceedings of the 44th ACM Technical Symposium on Computer Science Education (pp. 365-370).

Tsarava, K., et al. (2017). Training Computational Thinking: Game-Based Unplugged and Plugged-in Activities in Primary School. In Proceedings of 11th European Conference on Game-Based Learning ECGBL 2017 (pp. 687-695).
Vitores, A., \& Gil-juárez, A. (2016). The Trouble with 'Women in Computing': A Critical Examination of the Deployment of Research on the Gender Gap in Computer Science. Journal of Gender Studies, 25(6), 666-680.

https:/ / doi.org/10.1080/09589236.2015.1087309

Voogt, J., Erstad, O., Dede, C., \& Mishra, P. (2013). Challenges to Learning and Schooling in the Digital Networked World of the 21st Century. Journal of Computer Assisted Learning, 29, 403-413.

Voogt, J., et al. (2015). Computational Thinking in Compulsory Education: Towards an Agenda for Research and Practice. Education and Information Technologies, 20, 715-728.

Vygotsky, L. S. (1978). Mind in Society: The Development of Higher Psychological Processes (M. Cole, V. J. Steiner, \& S. Ellen, Eds.). Harvard University Press

Wing, J. M. (2006). Computational Thinking. Communications of the ACM, 49(3), 33-35.

Yadav, A., Hong, H., \& Stephenson, C. (2016). Computational Thinking for All: Pedagogical Approaches to Embedding 21st Century Problem Solving in K-12 Classrooms. TechTrends, 60, 565568.

Yasar, O., Veronesi, P., Maliekal, J., Little, L. J., Vattana, S. E., \& Yeter, I. H. (2016). Computational Pedagogy: Fostering a New Method of Teaching. Computer in Education Journal, 16(3), 51-72.

Yochum, S. M., \& Luoma, J. R. (1995). Augmenting a Classical Electrochemical Demonstration. Journal of Chemistry Education, 72(1), 55-56. https://doi.org/ 10.1021/ed072p55

You, S. (2013). Gender and Ethnic Differences in Precollege Mathematics Coursework Related to Science, Technology, Engineering, and Mathematics (STEM) Pathways. School Effectiveness and School Improvement, 24(1), 64-86. 


\section{APPENDIX}

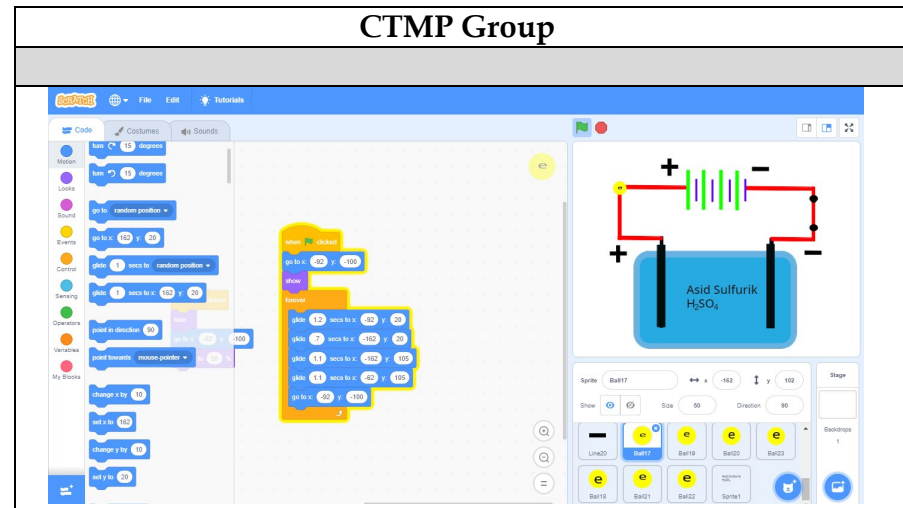

Student's Task (Electrolyte and non-electrolyte)

Part of the electrolysis set drawings have been prepared and students just need to:

- Choose one of the electrolytes solution $\left(\mathrm{H}_{2} \mathrm{SO}_{4}, \mathrm{C}_{2} \mathrm{H}_{5} \mathrm{OH}\right.$, $\mathrm{NaOH}$ and $\mathrm{NH}_{3}$ ) that have been given from the task.

- Build the electron sprite and do the animation of the movement in the electrolysis set circuit.

- Build the sprite for the chosen solution

CT Skill

- Generalisation - Electrolyte and non-electrolyte

- Algorithmic thinking - Programming

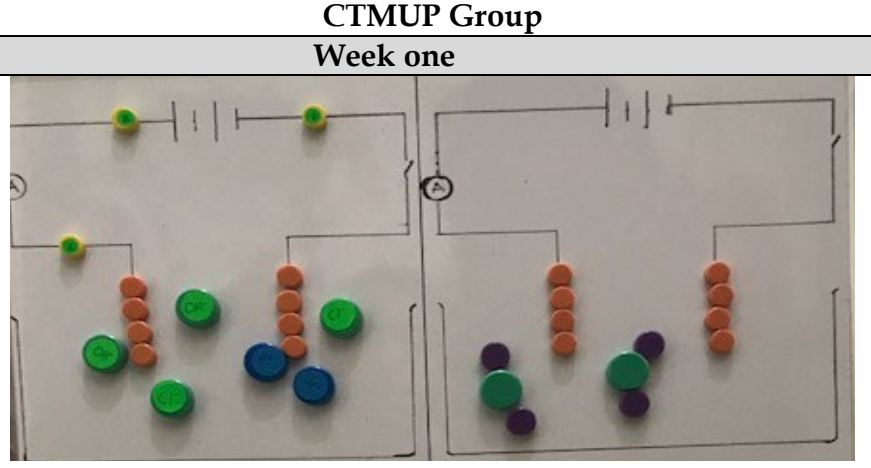

Student's Task (Electrolyte and non-electrolyte)

Part of the electrolysis set drawings have been prepared and students just need to:

- Choose one of the electrolytes solution $\left(\mathrm{H}_{2} \mathrm{SO}_{4}, \mathrm{C}_{2} \mathrm{H}_{5} \mathrm{OH}\right.$, $\mathrm{NaOH}$ and $\mathrm{NH}_{3}$ ) that have been given from the task.

- Write the electrons and ions or the particles presence on the provided stickers. Students paste the sticker on the magnet and explain the concept of electrolyte and non-electrolyte.

CT Skill

- Generalisation - Electrolyte and non-electrolyte

- Algorithmic thinking - Steps that have been done to solve the task

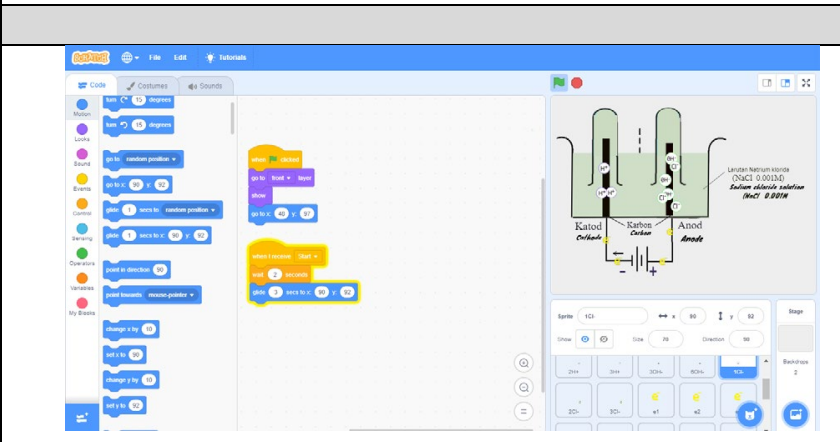

Student's Task (Electrochemical series factors)

Part of the electrolysis set drawings have been prepared and students just need to:

- Build the sprite of the presence ions (anions and cations) and move them towards the anode and cathode.

- Build the sprite of electrons and make the moving animation in electrolysis set circuit.

- Build the sprites by writing the half equations at the anode and cathode.

\section{CT skill}

- Algorithmic thinking- Do the programming, arrange the sequence of anions and cations in order to decide the discharged ions.

- Abstraction - Based on few steps, students need to choose the important steps only.

- Generalisation - Anode electrode will release electrons and cathode electrode will gain electron. Anions will flow towards anode and cation will flow towards cathode.

- Evaluation - After the coding process, students will evaluate the animation or the whole display. Adjustment process will be done if there is any deficiency.

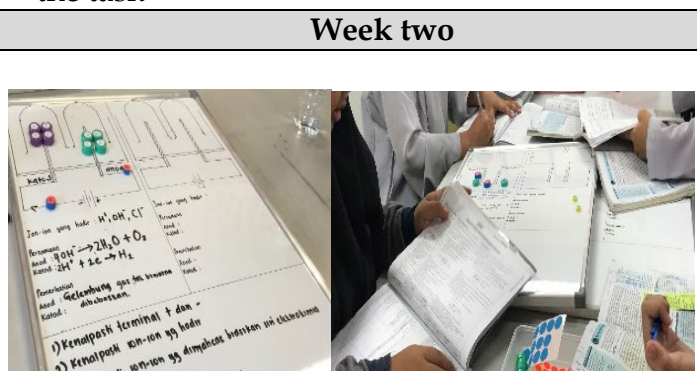

\section{Student's Task (Electrochemical series factors)}

The electrolysis set drawings have been prepared and students just need to:

- Write the electrons and ions or particles presence on the stickers provided. Then, students need to paste them on the magnet.

- Write the half equations on the anode and cathode.

- State the observation on the anode and cathode.

- Explain the selection of ions to be discharged and electrolysis factors.

\section{CT skill}

- Algorithmic thinking- Arrange the sequence of anions and cations in order to decide the discharged ions.

- Abstraction - Based on few steps, students need to choose the important steps only.

- Generalisation - Anode electrode will release electrons and cathode electrode will gain electron. Anions will flow towards anode and cation will flow towards cathode.

- Evaluation - Students need to re-evaluate whether the observations and equations on the anode and cathode are matched.

Figure A1. Application CT Skills in the CTMP and CTMUP Groups in week one until week two 


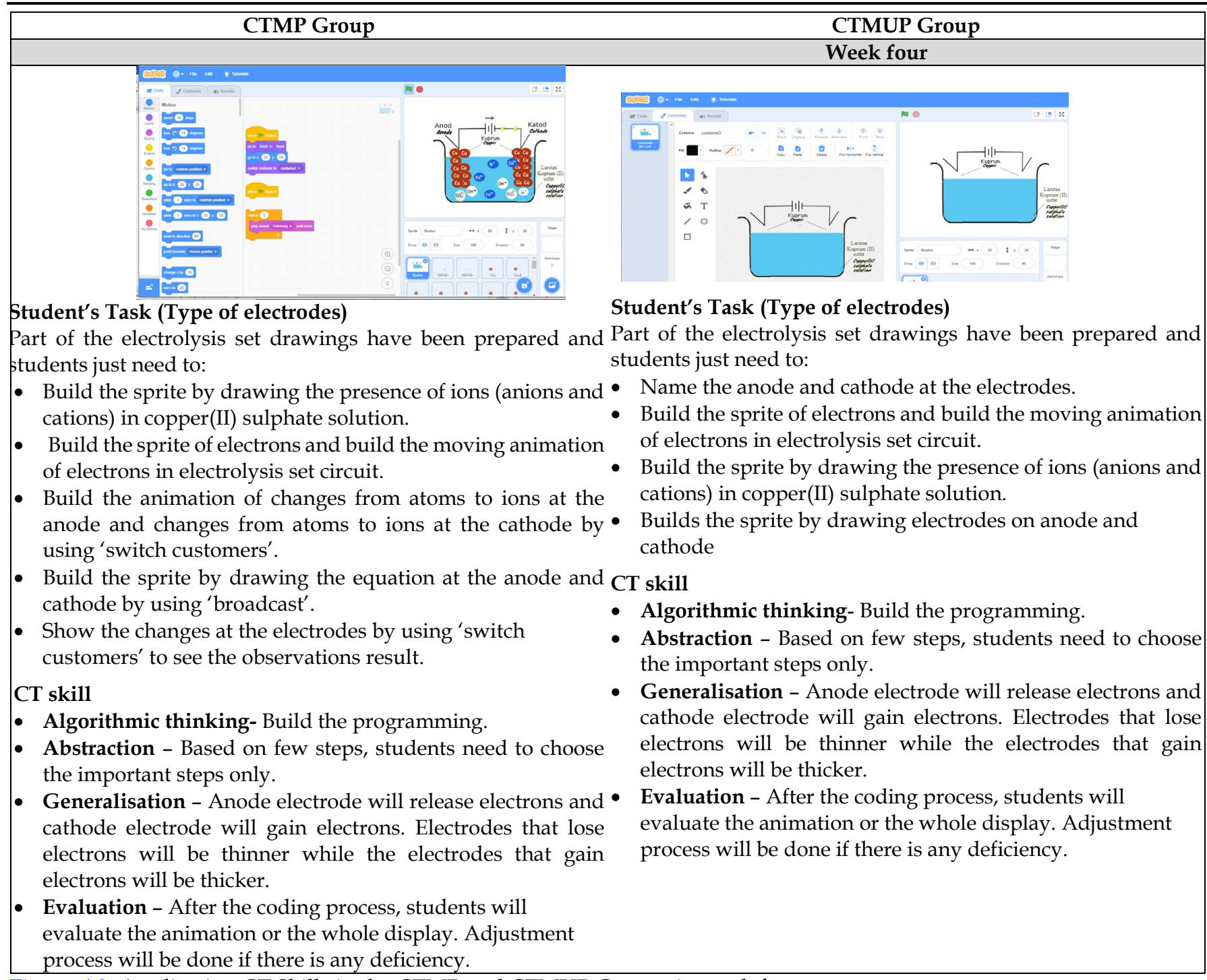

Figure A2. Application CT Skills in the CTMP and CTMUP Groups in week four 
Tasks

You are given the materials and apparatuses as below to create a project on the process of metal plating

- Copper electrode

- Aqueous 0.5 moldm $^{-3}$ copper(II) sulphate solution

- Copper electrode

- Iron key

The project created should comprise the following:

- Determine the negative and positive terminals and the anode and cathode

- Determine the direction of the electron flow

- Demonstrate the process of electroplating of iron key

- Demonstrate the process of copper ion and atoms (copper metal) formation

- Observations at the anode and cathode.

- Write half equations at the anode and cathode

- Name the product produced at anode and cathode
You are given materials and apparatuses as below to create a project on the process of electrolysis

- Aqueous 2.0 moldm $^{-3}$ copper(II) chloride solution

- Carbon electrode

The project created should comprise the following :

- Determine the negative and positive terminals and the anode and cathode

- Determine the direction of the electron flow

- Demonstrate the process of electrolysis

- Demonstrate the observation at anode and cathode

- Write half equations at the anode and cathode

- Name the product produced at anode and cathode

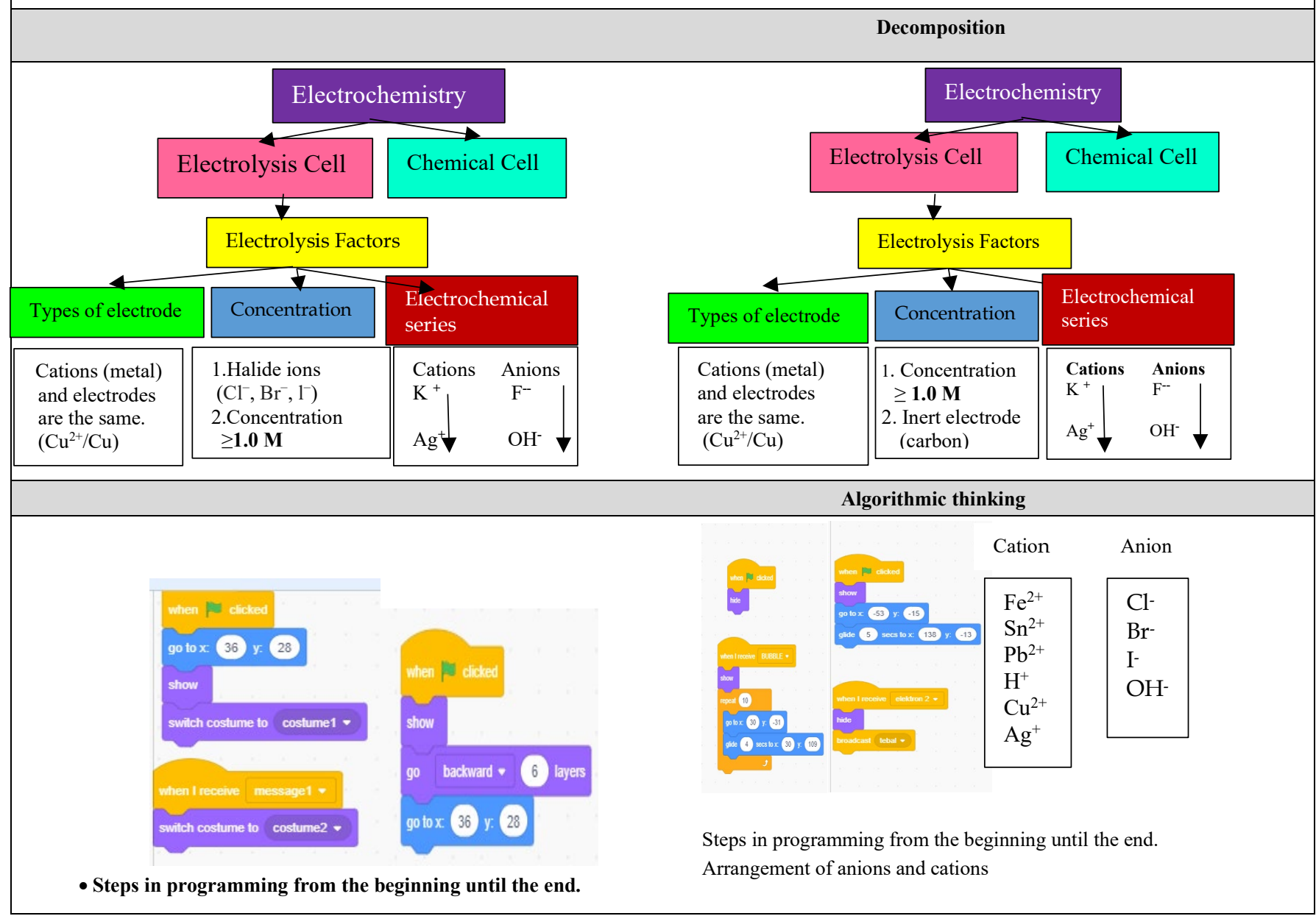

Figure A3. Application CT Skills in Decomposition and Algorithmic Thinking based on the Task Sample in the CTMP and CTMUP Groups 


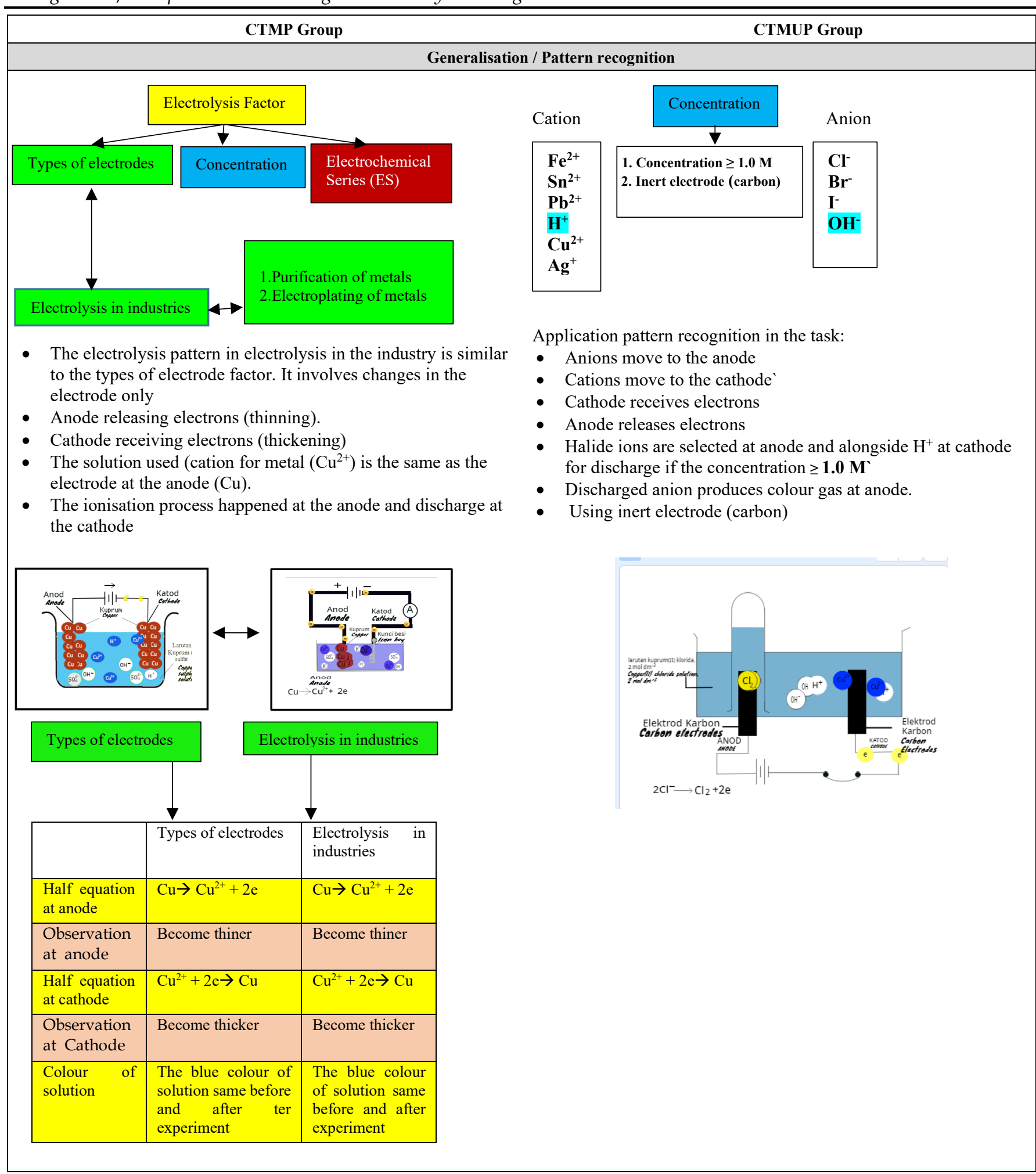

Figure A4. Application of CT Skills in Generalisation in the CTMUP Group and CTMP Group 
- Identify cations (metals) on the solution

- Determine the electrode used in the cathode (metal similar to cation ( metal)

- Determine the negative (cathode) and positive (anode) terminals in the electrolysis diagram.

- Determine the position of the anode and cathode. The metal to be plated must be at the electrode (cathode), and the metal plating must be at the anode

- Ionisation process at the anode and discharge at the cathode.

- Organise the steps in the process of creating Scratch and subsequently produce a Scratch project.

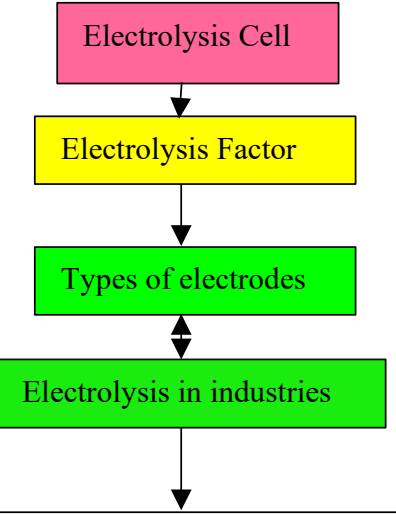

- Determine the position of the electrode (copper metal) and the metal key

- Identify the cation in the solution (metal ion)

- The ionisation process happened at the anode and discharged at the cathode

\section{Abstraction}

- Students write only the important steps involved in solving problems in the given task

- Determine the negative terminal (cathode) and positive (anode) in the electrolysis diagram

- Determine the anions and cations present in the solution.

- Determine the ions discharged at the anode and cathode

- Observations and half equations

- Organise the steps in the process of creating Scratch and subsequently produce a Scratch project.

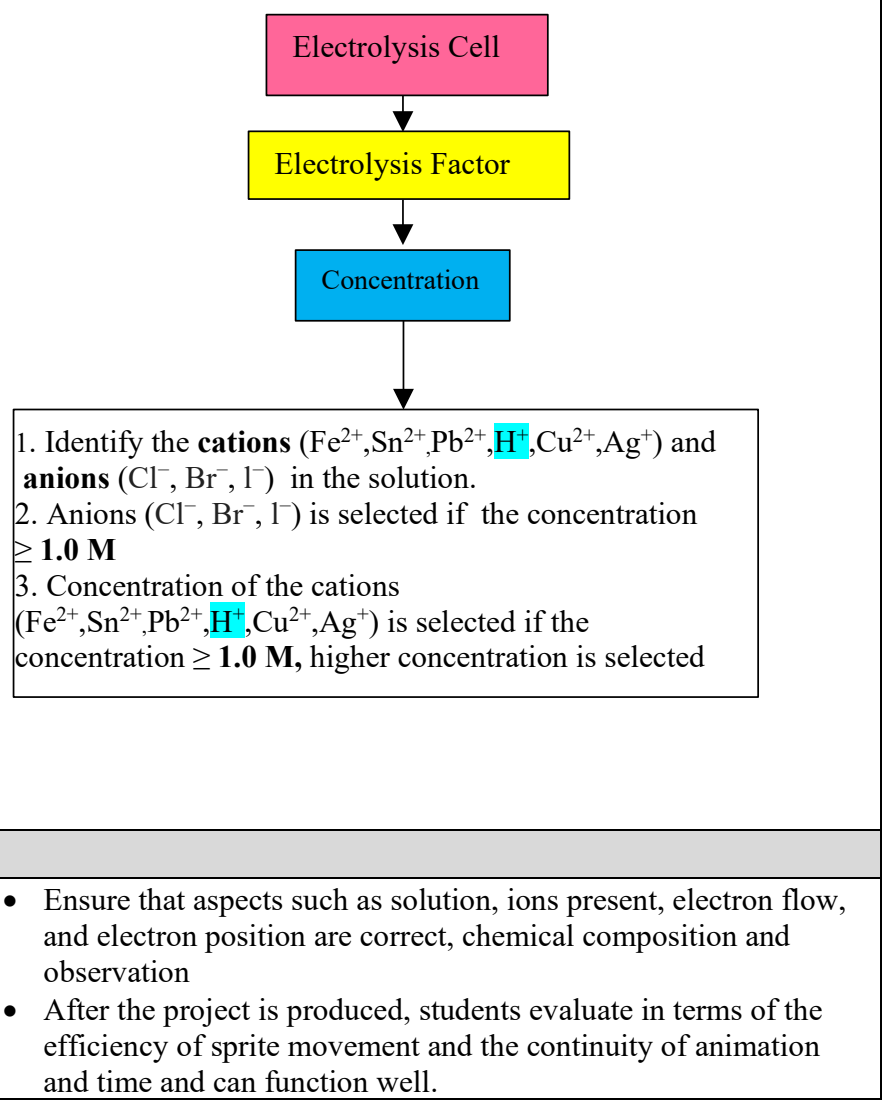
and time and can function well.

Ensure that aspects such as solution, ions present, electron flow, observation

After the project is produced, students evaluate in terms of the uation in the CTMUP Group and CTMP Group and electron position are correct, chemical composition and
- Ensure that aspects such as solution, ions present, electron flow, and electron position are correct, chemical composition and observation

- After the project is produced, students evaluate in terms of the efficiency of sprite movement and the continuity of animation and time and can function well.

\section{http://www.ejmste.com}

